بر آورد سطح يوشش برف در سطح شهرستان اردبيل و سرعين با استفاده از دادههاى سنجنده MSI ماهواره Sentinel 2

\author{
صياد اصغرى سراسكانرود ا* و ريحانه مديرزاده

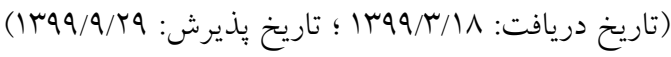

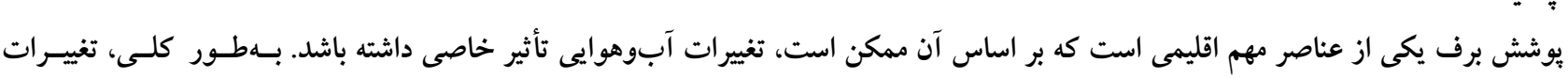

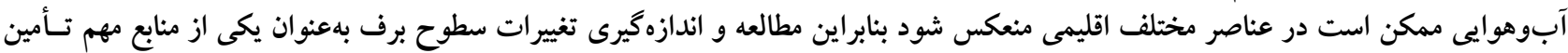

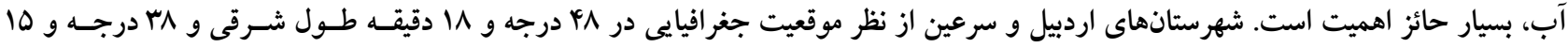

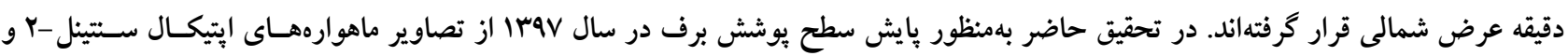

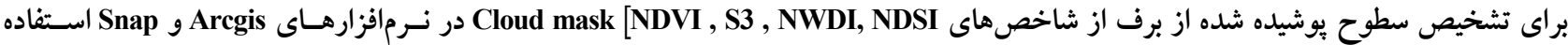

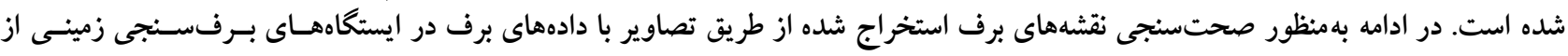

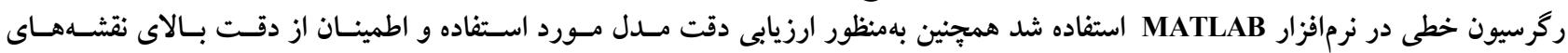

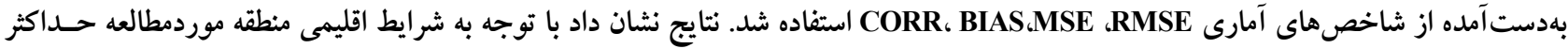

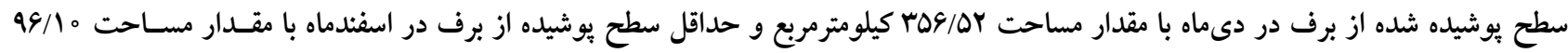

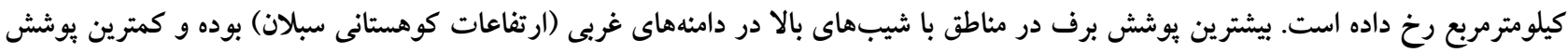

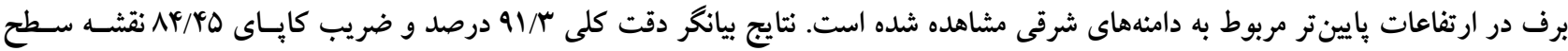

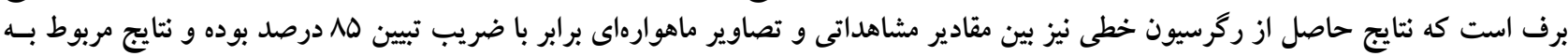

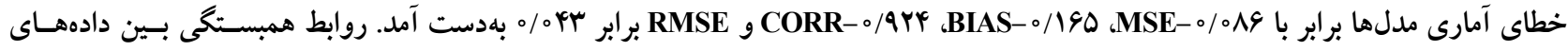

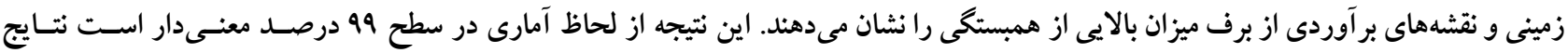

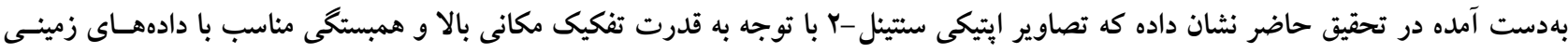

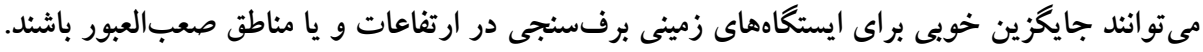

وازمهاى كليدى: سطح يوشش برف، ستينل -Y، شاخص NDSI، شاخص S3، سرعين، اردبيل

ا. كروه جغرافياى طبيعى، دانشكده ادبيات و علوم انسانى، دانشخاه محقق اردبيلى

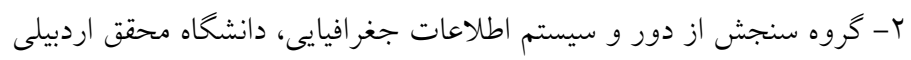

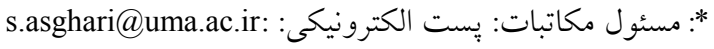


يوشش يخ است و هميخنين ستتينل -r كارايى بهترى نسبت بـه

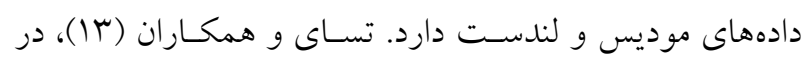

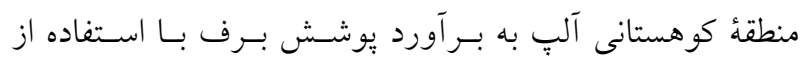
دادهــاى سـتتينل -r و استفاده از شـاخصهــاى NDSI، S3 و

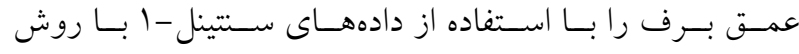

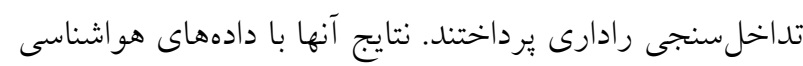

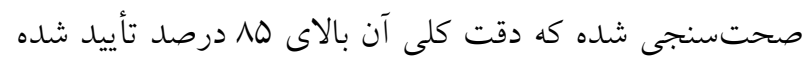

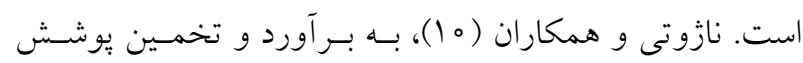

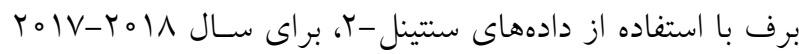
در حوضهٔ مييار و بغا از مناطق غربى هيماليا در منطقه لاهول با بالي

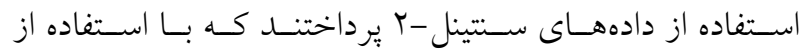

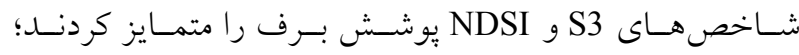
مساحت نقشه هاى يوشش برفى بهدست آورده شده براى سـال

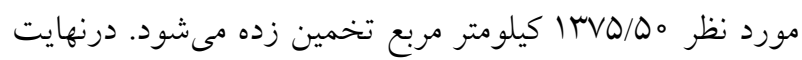

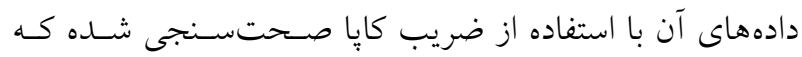

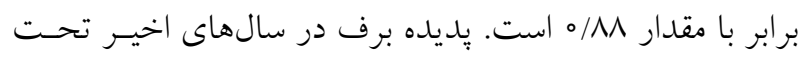

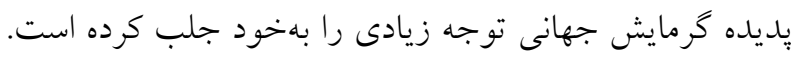

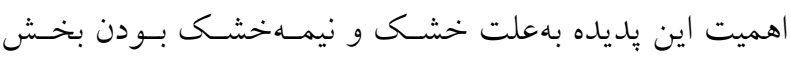

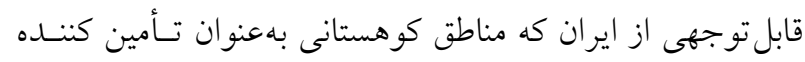

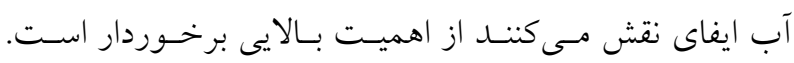

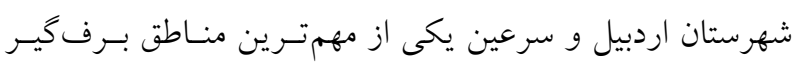

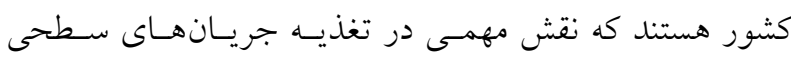

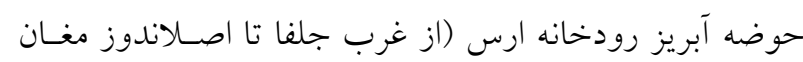

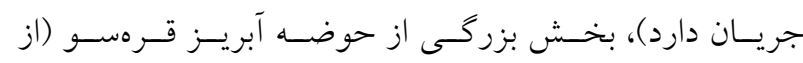

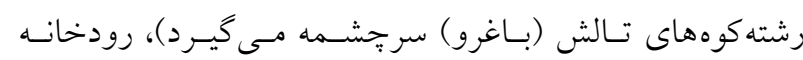

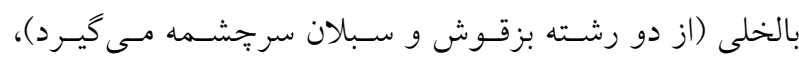

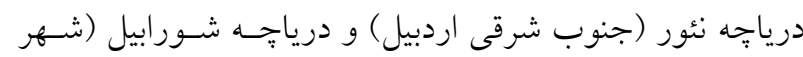

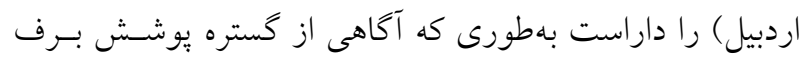

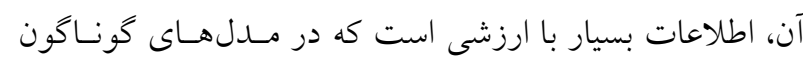

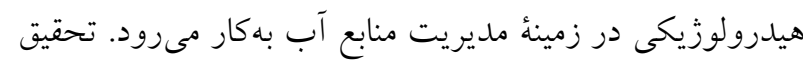

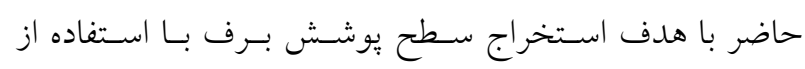

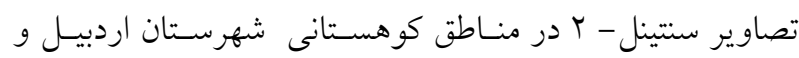

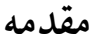

برف يكى يديده معمول هواشناسى جهانى است كه بهعنوان يك جزء مهم جرخه هيدرولوزيكى و يك خطر محيط زيست

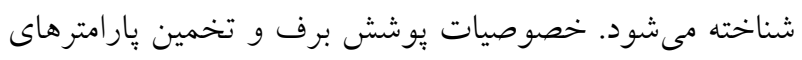

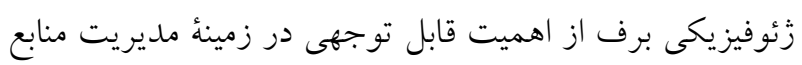

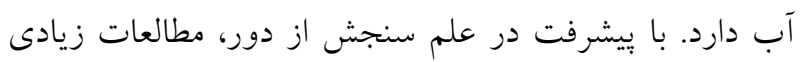

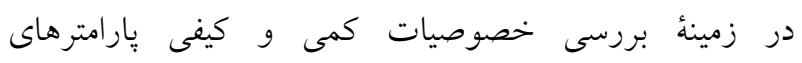
زئوفيزيكى برف صورت كرفته است. با اين حال، بسيارى از

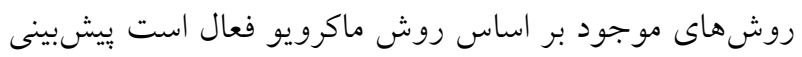

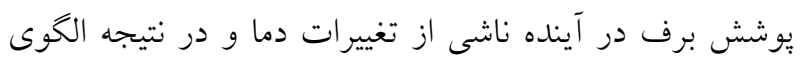

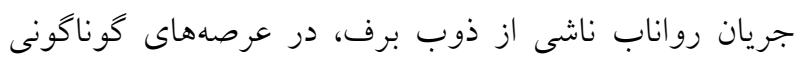
مرتبط با برف كاربرد دارد (ه). ورد و همكاران (4) (1)، به برآورد سطح يوشش برف بـا اسـتفاده از دادهاى سنتينل -T، در هيماليا، با استففاده از بازتـاب مـادون قرمز نزديك (NIR) و شاخصهاى (NDSI) و(S3) به بـرآورد

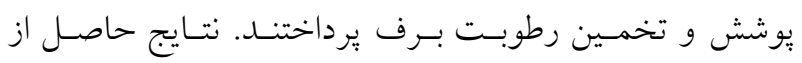

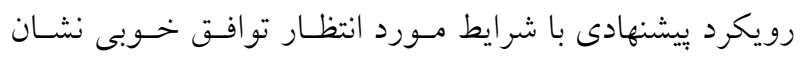

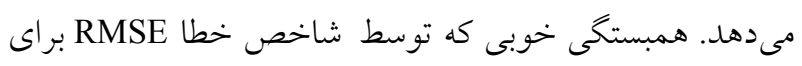

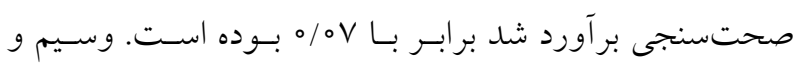

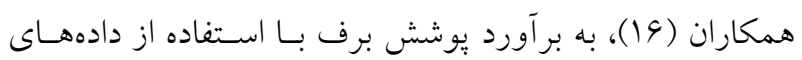

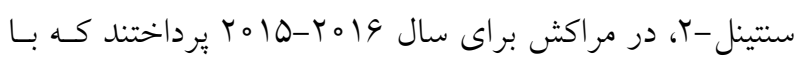

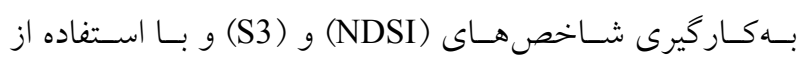

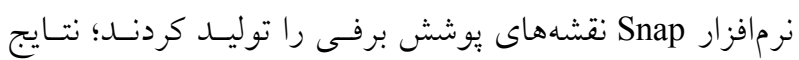

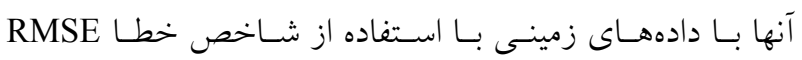

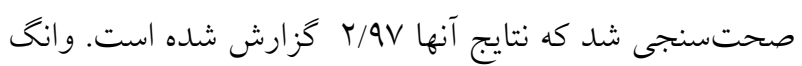

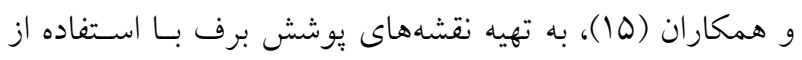

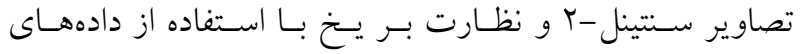

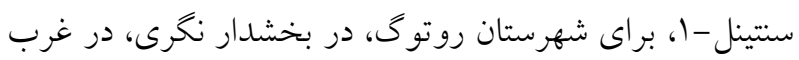
تبت كه با استفاده از شاخصهـاى (NDSI) و (S3) يرداختنـد؛

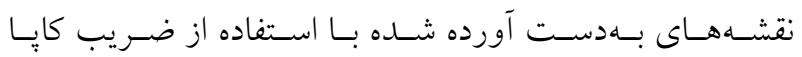

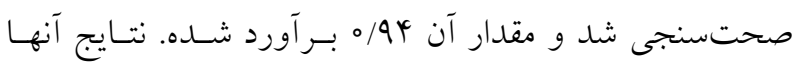

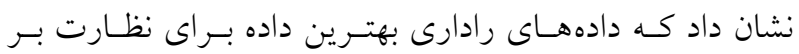




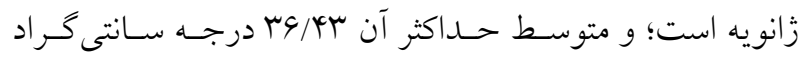

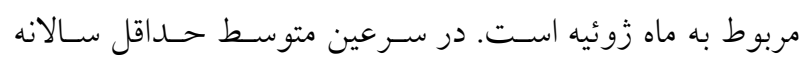

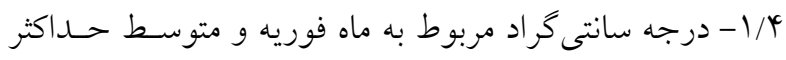

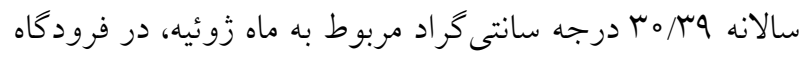

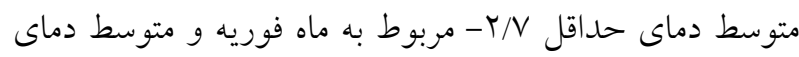

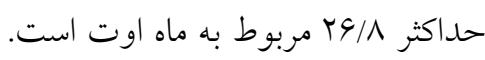

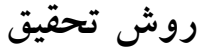

بـهمنظـور بررسـى سـطح يوشـش بـرف، ابتــا جهار تصـوير

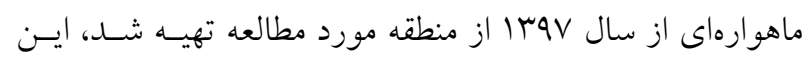

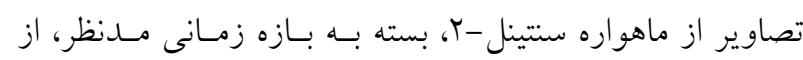

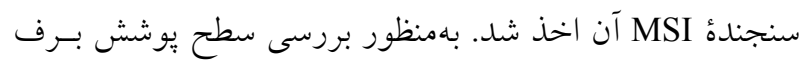

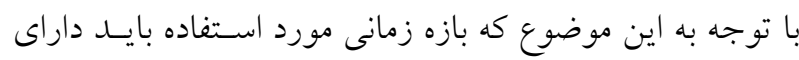

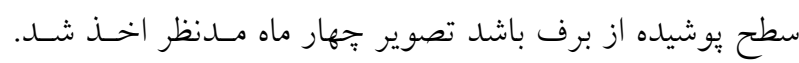

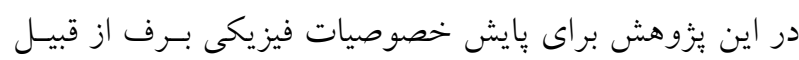

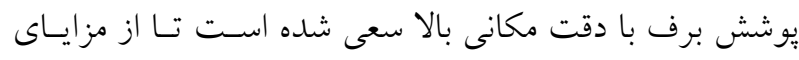

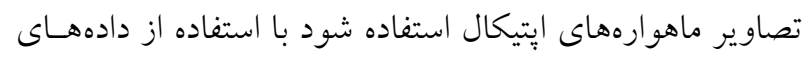

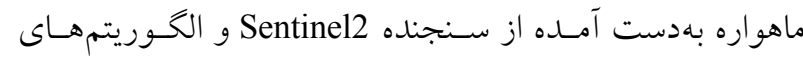
تخمن Cloud mask ،NDSI ،NDWI ،S3 ،NDVI تخمين زده شده و مساحت آن بهدست آمده است.

\section{Sentinel2 ماهواره}

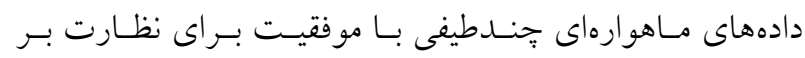

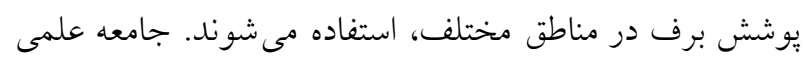

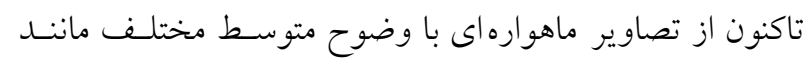
MODIS AWIFS Landsat (OLI،TM ،MSS) نقشه بردارى از منطقه يوششى از بـرف اسـتفاده كـرده اسـت.

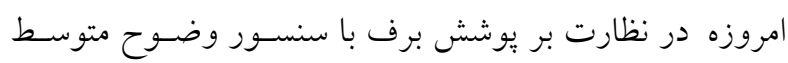

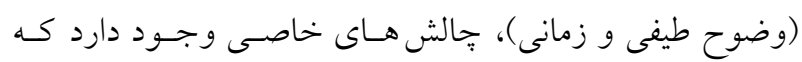

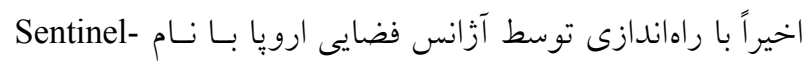

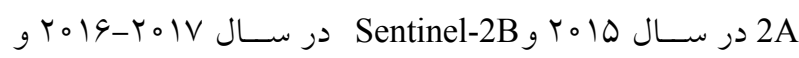

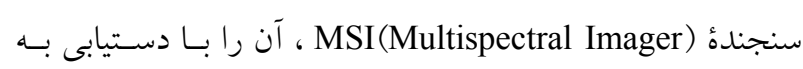

سرعين انجام شده است كه منطقه مـورد مطالعسه بـين عـرض

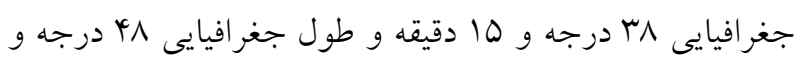

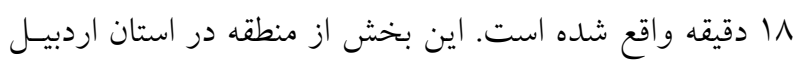

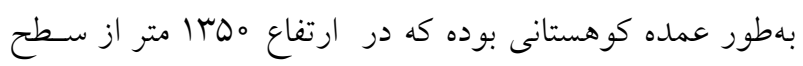
آبهاى آزاد قرار كرفته است.

\section{مواد و روشها - (- ماد} موقعيت جغر افيايى منطقه

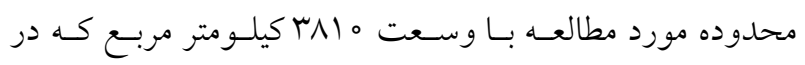

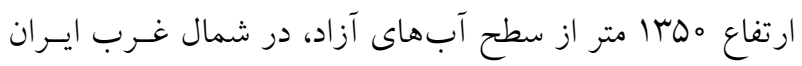

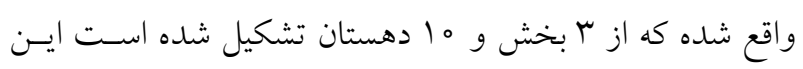

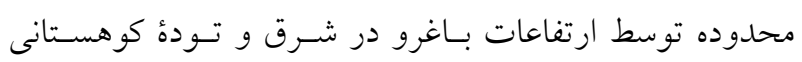

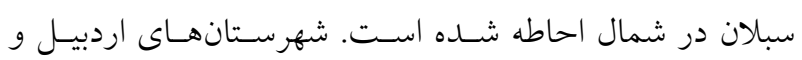

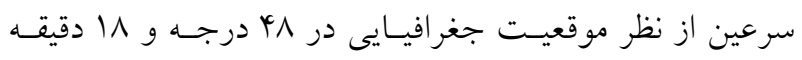

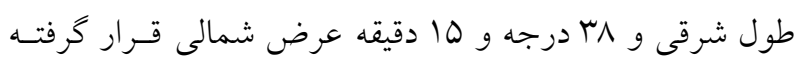

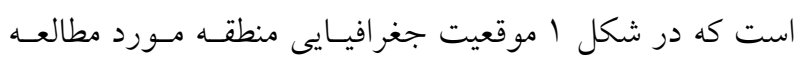

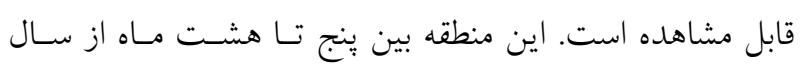

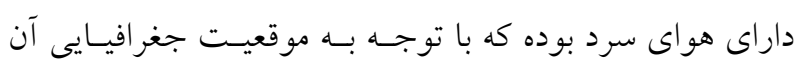

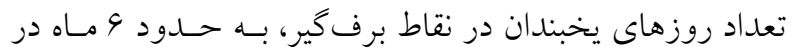

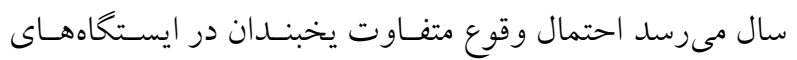

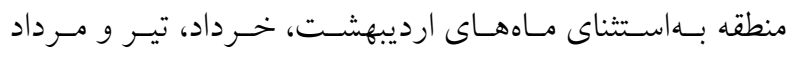

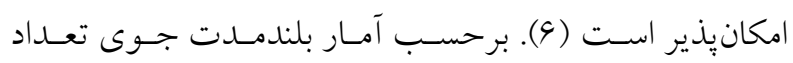
روزهاى يخبندان ماهانه در طول دورة آمارى مـورد مطالعـهُ رخخ

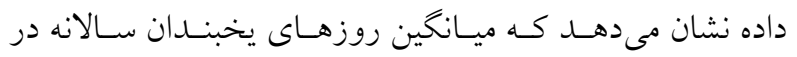

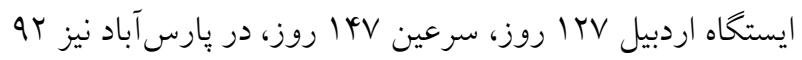

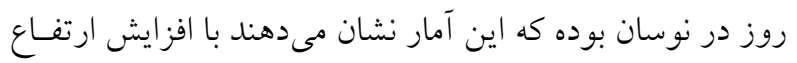

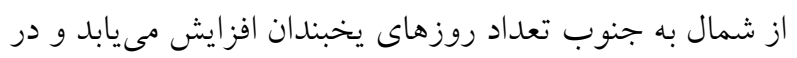

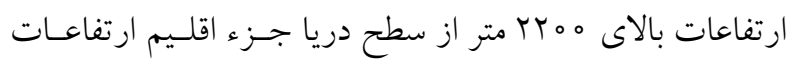

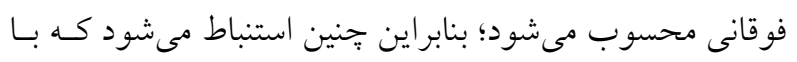

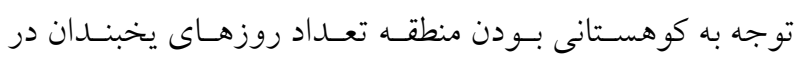

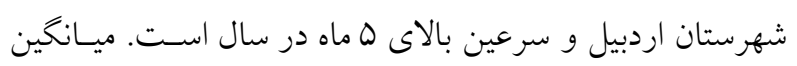

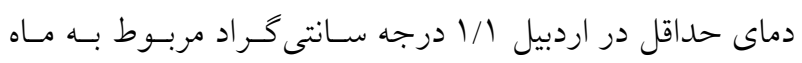




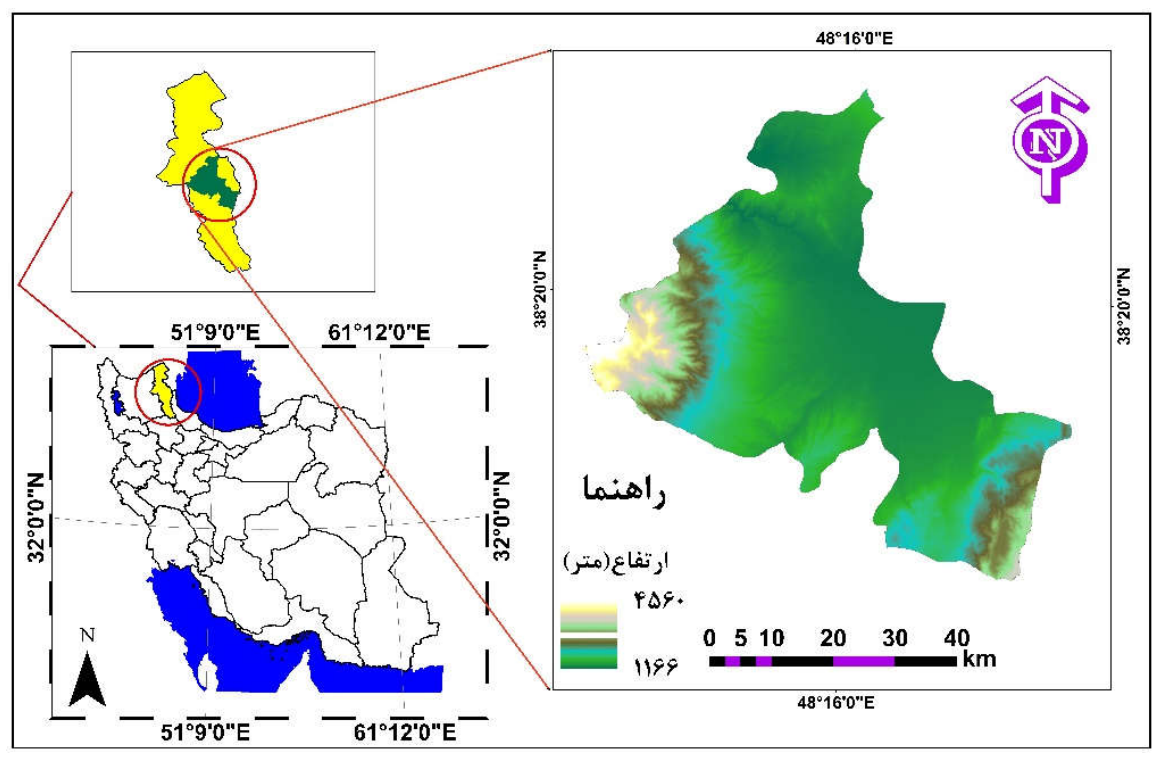

شكل ا. موقعيت محدوده مورد مطالعه

سطح يوشش برف تجمع برف نشانخر تنوع قوى در مقياسهـاى زمـانى و مكـانى

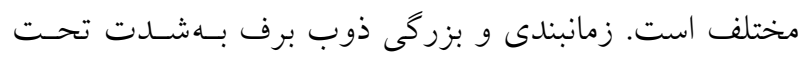
تأثير تغييريذيرى تغييرات آب و هوا است. دماى گرمتـر ميـزان

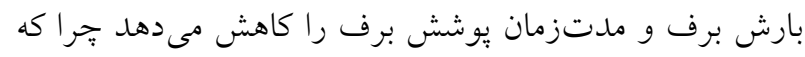

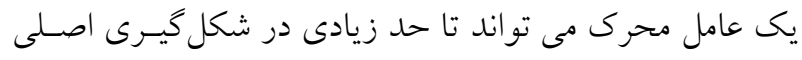

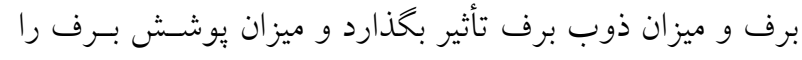

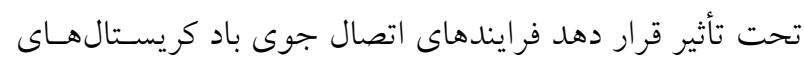

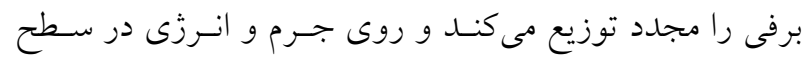

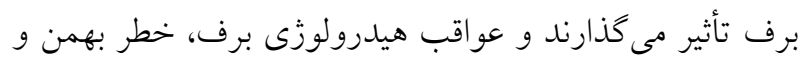

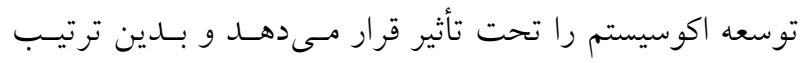

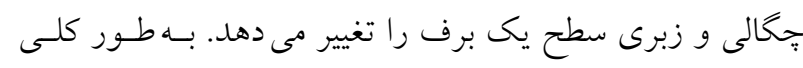

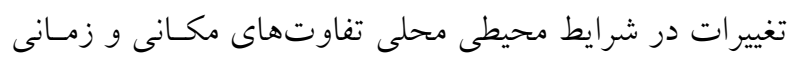

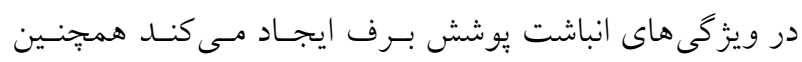

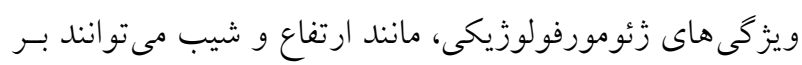

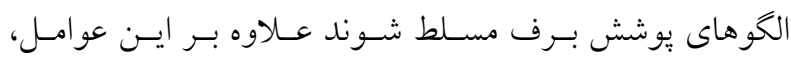

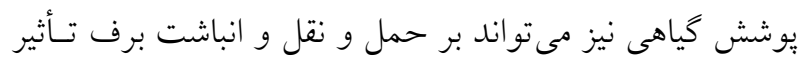

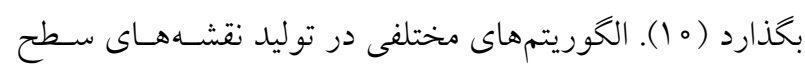

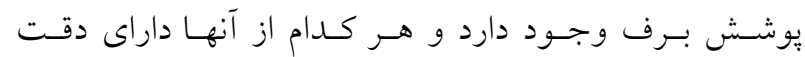

دادههاى جندطيفى در را باند مىتوان يوشش برف را بهدست

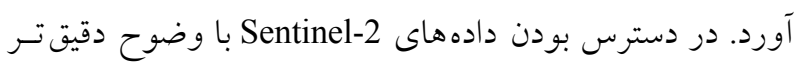

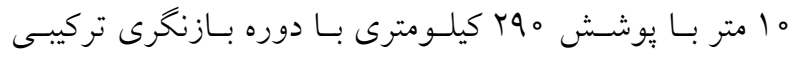

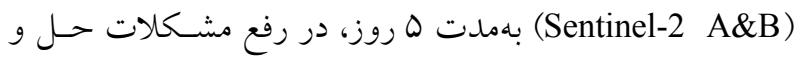

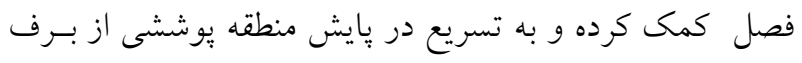

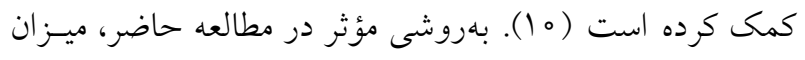

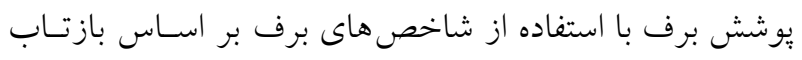

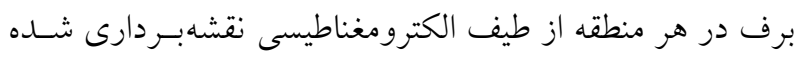

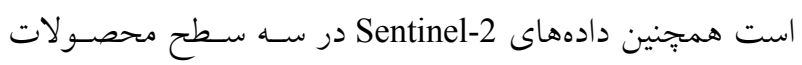

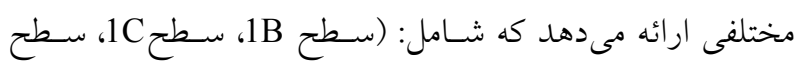

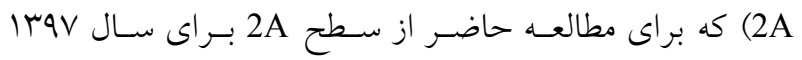
استفاده شده است. جدول ا نوع تصاوير استفاده شده مـاهواره Sentinel2 را نشان مىدهد. دادههاى ياد شده، علاوه بر تفكيك مكانى مناسب از تفكيك رهان

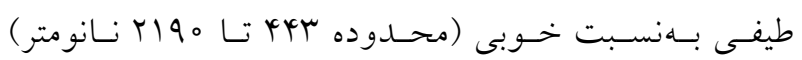

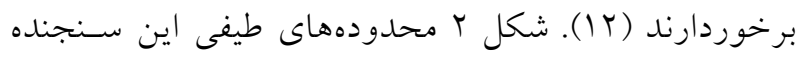
را نشان مى دهد. جدول Y مشخصات كلى باندهاى ماهو اره سنتينل -Y بههمر اه كاربردشان را نمايش مى دهد. 
جدول ا. نوع تصاوير استفاده شده ايتيكال ماهواره Sentinel2

\begin{tabular}{|c|c|c|c|c|}
\hline ماهواره & تصويربردارى باند & تفكيك مكانى & فرمت & تصويربردارى تاريخ \\
\hline Sentinel2 & msi & $10 \mathrm{~m}$ & Tif & $Y 0 \mid \Lambda / 01 / 1 \Lambda$ \\
\hline Sentinel2 & $\mathrm{msi}$ & $10 \mathrm{~m}$ & Tif & $Y_{0} \mid V / I Y / Y_{0}$ \\
\hline Sentinel2 & msi & $10 \mathrm{~m}$ & Tif & $Y \circ|N / O Y /| Y$ \\
\hline Sentinel2 & msi & $10 \mathrm{~m}$ & Tif & $r \cdot \mid \Lambda / \circ r / \Lambda$ \\
\hline
\end{tabular}

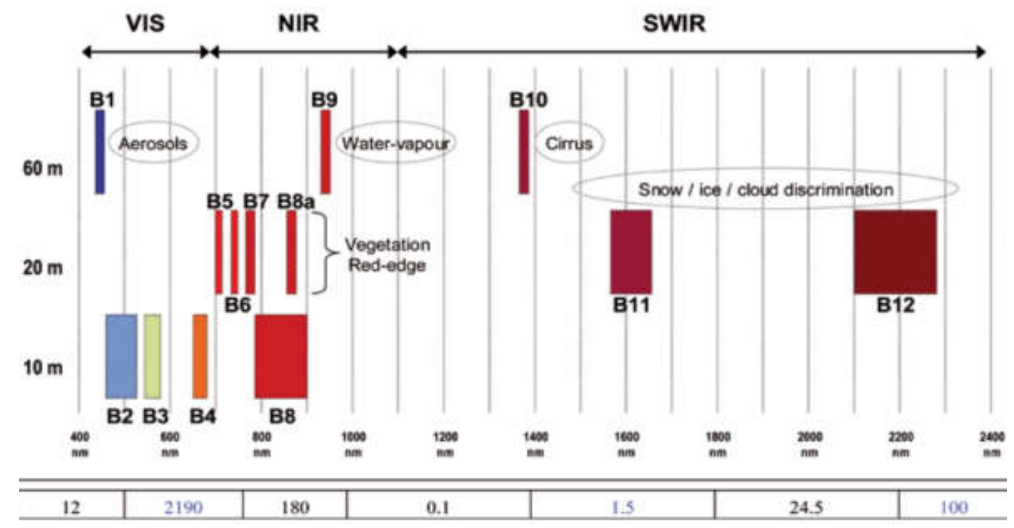

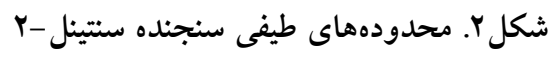

جدول r. جاطلاعات باندهاى سنتينل

\begin{tabular}{|c|c|c|c|c|c|}
\hline سنجنده & توان تفكيك مكانى (متر) & ميانخين طول موج & هدف و كاربرد & 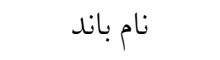 & شماره باند \\
\hline MSI & 90 & M & تشخيص آئروسل & Coastal aerosol & 1 \\
\hline MSI & 10 & $\circ / 4 q$ & 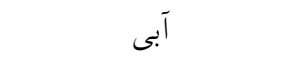 & Blue & r \\
\hline MSI & 10 & $\circ / 09$ & سبز & Green & r \\
\hline MSI & 10 &.$/ 90$ & 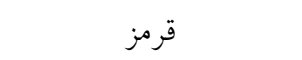 & Red & c \\
\hline MSI & $r_{0}$ & $\circ / V_{0}$ & طبقهبندى يوشش گياهى & $\begin{array}{l}\text { Vegetation Red } \\
\text { Edge }\end{array}$ & 0 \\
\hline MSI & $r_{0}$ & $\circ / Y^{4}$ & طبقهبندى يوشش گياهى & $\begin{array}{l}\text { Vegetation Red } \\
\text { Edge }\end{array}$ & 9 \\
\hline MSI & $r_{0}$ & $\circ / \mathrm{V} \wedge$ & طبقهبندى يوشش گياهى & $\begin{array}{l}\text { Vegetation Red } \\
\text { Edge }\end{array}$ & V \\
\hline MSI & 10 & $\circ / \Lambda Y^{4}$ & 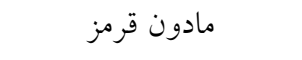 & NIR & $\wedge$ \\
\hline MSI & ro & $\circ / \wedge 9$ & مادون قرمز نزديك & Narrow NIR & 9 \\
\hline MSI & 9. &.$/ 94$ & بخار آب & Water vapour & 10 \\
\hline MSI & 90 & $1 / T V$ & سيروس & SWIR - Cirrus & 11 \\
\hline MSI & ro & $1 / 91$ & برف / يخ / ابر & SWIR & ir \\
\hline MSI & ro & $r / 19$ & برف / يخ / ابر & SWIR & Ir \\
\hline
\end{tabular}




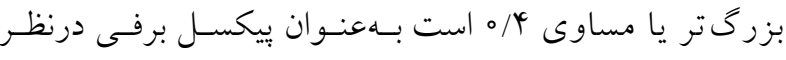

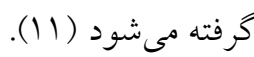
NDSI $=\frac{\text { Green }- \text { Swir }}{\text { Green }+ \text { Swir }}=\frac{\mathrm{B}_{3}-\mathrm{B}_{11}}{\mathrm{~B}_{3}+\mathrm{B}_{11}}$

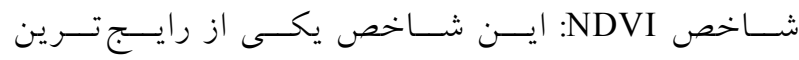

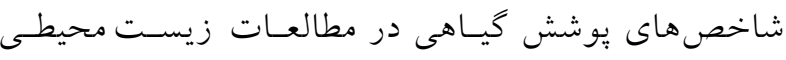

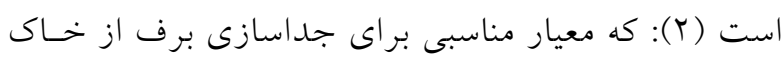

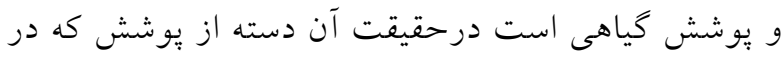

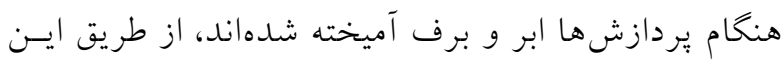

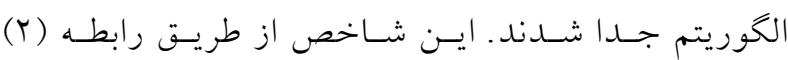

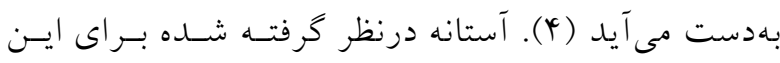
الكوريتم در تحقيق حاضر، بالاتر از ه/ه است:

$$
\text { NDVI }=\frac{\text { Nir }- \text { Red }}{\text { Nir }+ \text { Red }}=\frac{B_{8}-B_{4}}{B_{8}+B_{4}}
$$

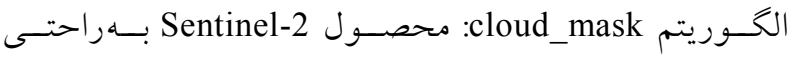
حاوى ماسكبردارى ابــر اسـت كـهـ بـهــــــوان محصـولى از

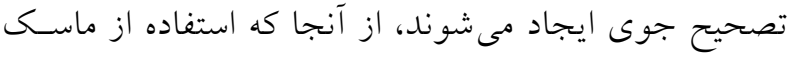

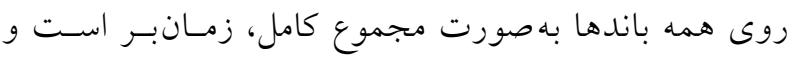

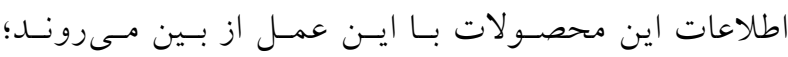

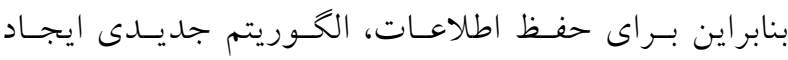

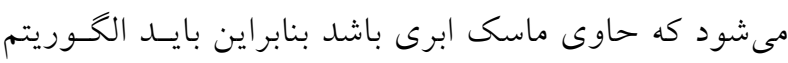

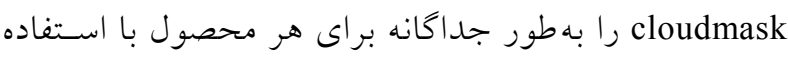
از BandMaths اضافه كرد (1) به (1)

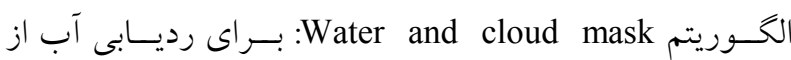

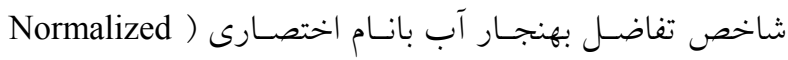
NDWI(difference water (1999)(McFeeters)

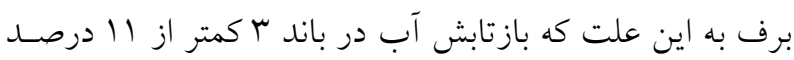

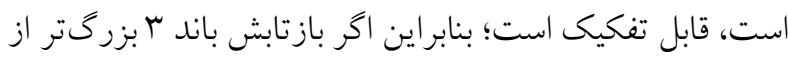

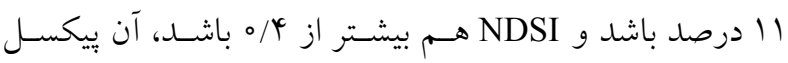

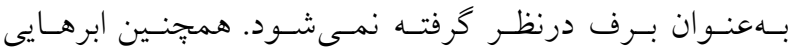

مCفاوتى در يبشبينى رواناب هستند بهطور مثال الكوريتم SCA

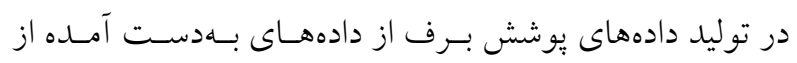

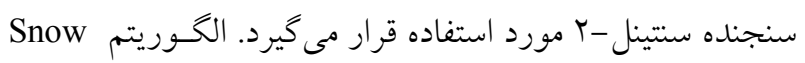

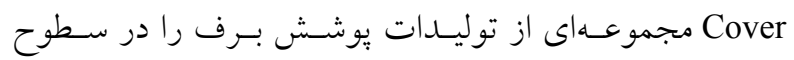

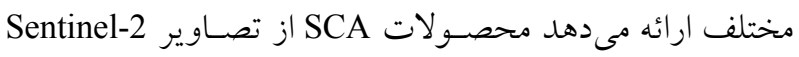
بر اساس يردازنده MAJA, LIS توليــد مسىشـوند كـه MAJA

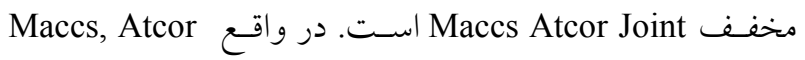
نرم افزارهـاى تصـحيح جـوى هستـند كـه توسط مركـز ملى مطالعـات فضـايى NenES (National Centre for Space Center for the ( و مركز مطالعه زيست كـره از فضـا Studies) CESBIO(Study of the Biosphere from Space است (ه): خروجى MAJA محصولى از سـطح 2A اسـت كـه توسط يردازنده LIS براى تعيين سطح يوشش برف درف در وضسوح

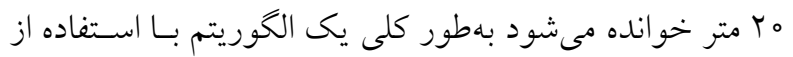

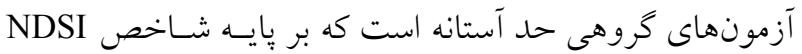

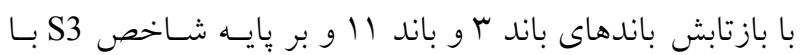

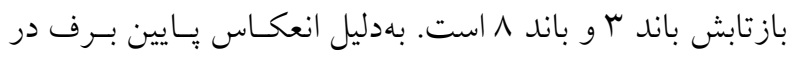

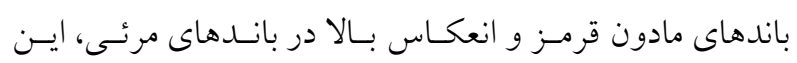

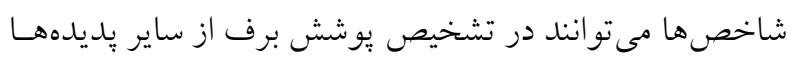

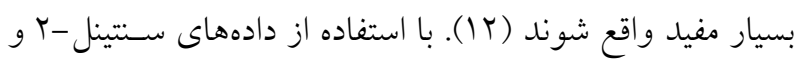

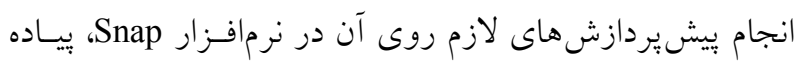

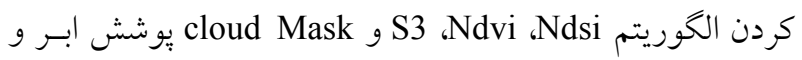
برف و يوشش گياهى مختلط شده با برف بهصسورت جداگانسه

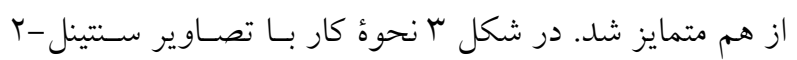

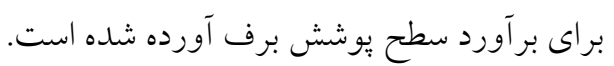

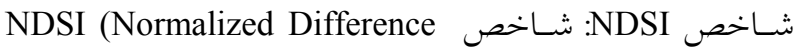
يك روش مؤثر براى تمايز برف از بسـيارى Snow Index) خصوصيات سطح ديخر است (^). اين شاخص را مى توان از رابطهُ (1) محاسبه كرد كه از نسبت اختلاف باز تابندكى باند مرئى (B33) سنجنده و مادونقرمز ميانى (B) تقسيم بر مجموع بازتابندكى در اين دو باند بهدست مى مهى آيد و در تهيه نقشه يوشش برفى زمانى كه بيكسل داراى NDSI 


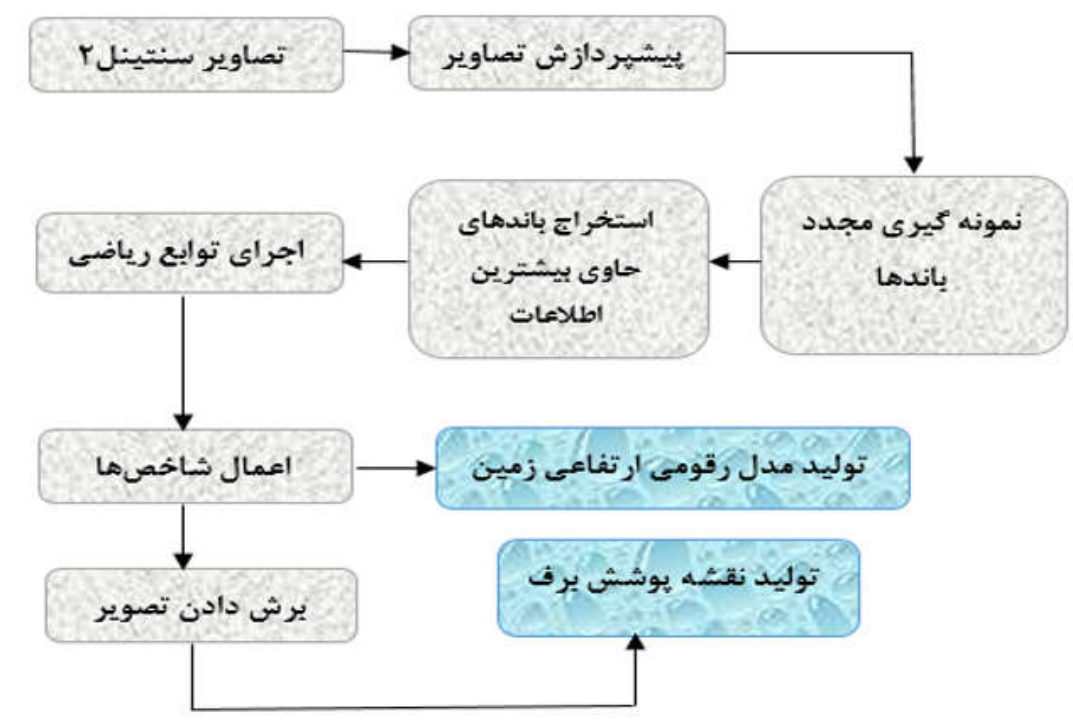

شكل r. دياگرام كار با تصاوير سنتينل -Y براى برآورد سطح بوشش برف

رابطه (Y) محاسبه مى شود (11):

$$
\mathrm{S} 3=\frac{\mathrm{Nir}(\text { Red }- \text { Swir })}{(\text { Nir }+ \text { Red })(\text { Nir }+ \text { Swir })}=\frac{\mathrm{B}_{3}\left(\mathrm{~B}_{8}-\mathrm{B}_{11}\right)}{\left(\mathrm{B}_{3}+\mathrm{B}_{8}\right)+\left(\mathrm{B}_{3}+\mathrm{B}_{11}\right)}
$$

\section{يافته هاى تحقيت}

با اعمال الكوريتمهاى Cloud mask, NDVI,NDSI, S3 نقشههـاى سطح برف براى ماههاى مورد نظر استخراج شد. در مرحله بعد بـاـ

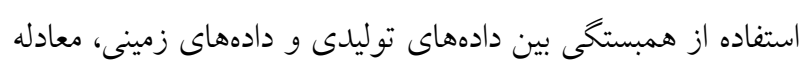

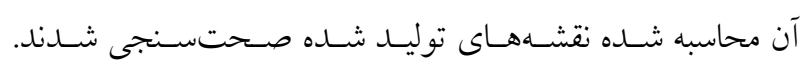

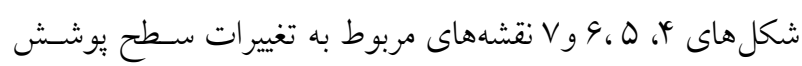

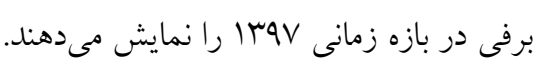

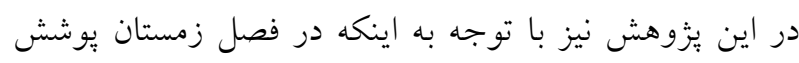

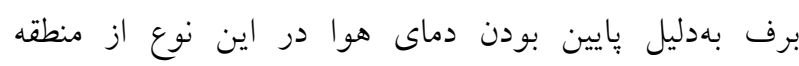

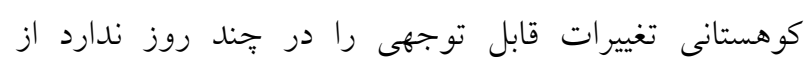
تصاوير سنجنده MSI سنتينل-r استفاده شد با اخذ دادههاى هواشناسى از ايستخاههاى موجود در منطقه جدول ب بيشترين

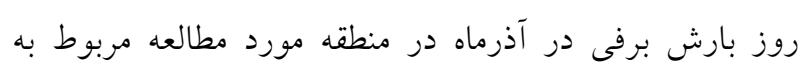

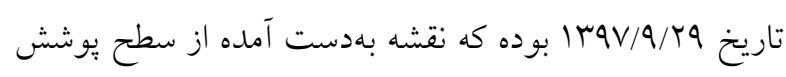

را كه در هر تصوير ورودى وجود دارد، بايد حذف شـود. براى اين منظور، يك ماسـك تركيبى از آب و ابـر ايجـاد

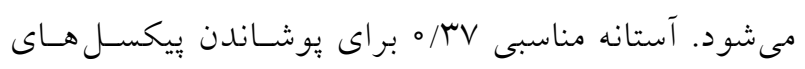
آب از بيكسل هاى برفى بهدست آمده است. ايسن شـاخص

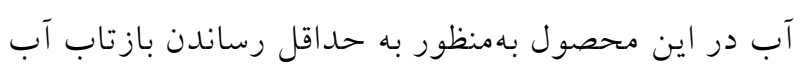
در باند NIR است كه از طريق رابطئ (r) بهدست مسى آيـد

NDWI $=\frac{\text { Green }- \text { Nir }}{\text { Green }+ \text { Nir }}=\frac{B_{3}-B_{8}}{B_{3}+B_{8}}$

Normal Snow ) شـاخص S3: شـاخص عـادى بـرف (Index در سال 1999 ارائه شده است؛ اين شاخص از مشخصـات بازتابى برف و يوشش كياهى استفاده مى كند تـا خطاهـاى

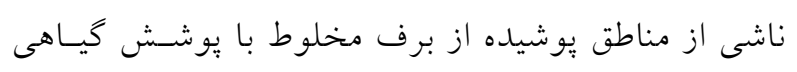

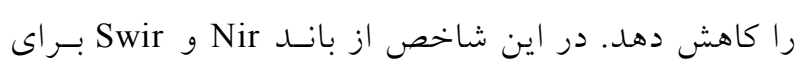
شناسايى برف در زير بيكسل هاى بوشش گيـاهى اسـتفاده

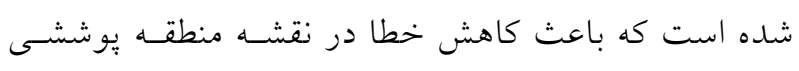

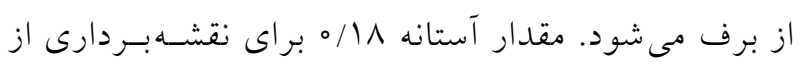
يوشش برفى استفاده شــده اسـت ايسن شـاخص از طريـق 
جدول r. موقعيت ايستخاههاى منطقه مورد مطالعه

\begin{tabular}{|c|c|c|}
\hline عرض جغرافيايى & طول جغر افيايى & ايستخاه \\
\hline rN/Ir & $Y \wedge / Y_{0}$ & اردبيل \\
\hline$r q / \circ r$ & $\Psi N / \circ \Delta$ & سرعين \\
\hline$\Gamma_{\Lambda / Y} \circ$ & YN/TO & فرو دگاه \\
\hline
\end{tabular}

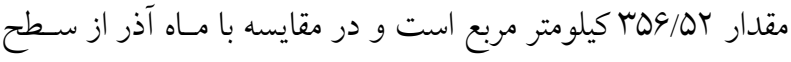
يوشش برف بيشترى برخوردار است.

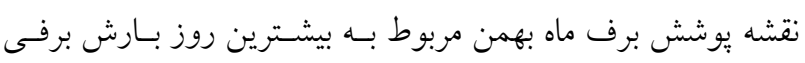

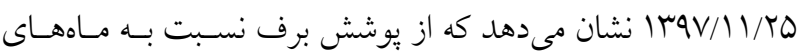

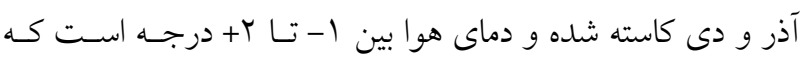
نشان مىدهد دماى هوا رو به حسداكثر اسـت در ايسن مــاه بيشـترين يوشش برف مربـوط بـهـ ارتفاعـات سـبلان و ارتفاعـات جنـوبى و

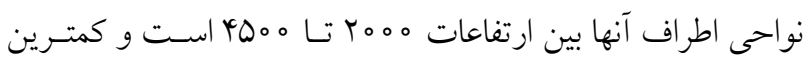
يوشش برف مربوط به سرعين، بخش هير، بخش مركزى شهرستان

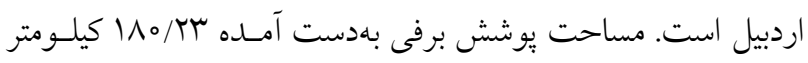

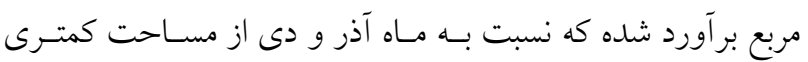
برخوردار است. يوشش برف ماه اسفند در بيشترين بارش برف در روز

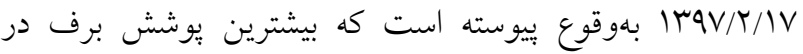

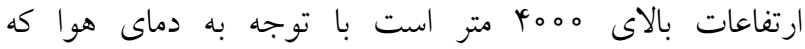
بين بأ+ تا ه+ درجه سانتى گراد است و همجنين تعداد روزهاى يخبندان در اين ماه بين •Y-10 است مىتوان كفت كه دماى هوا نسبت به ماههاى كذشته بيشتر شده و هم:حنين تعداد روزهاى

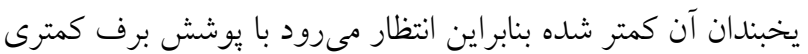

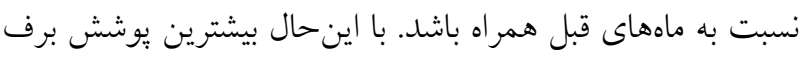

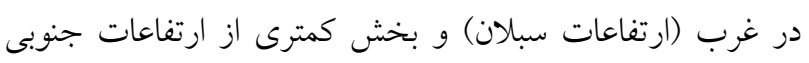

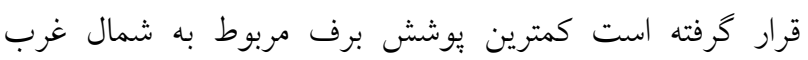

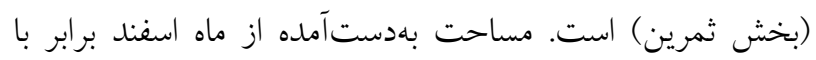
。 مساحت كمترى را بهخود اختصاص داده است.
برف آذرماه در شكل ^ץ نشان داده شده است كه با توجه به

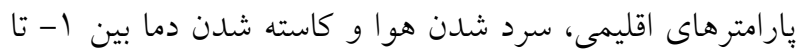

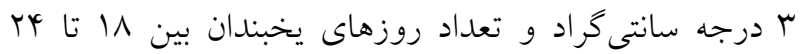

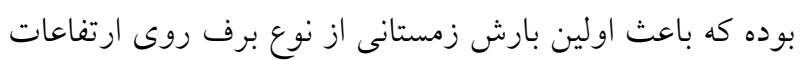

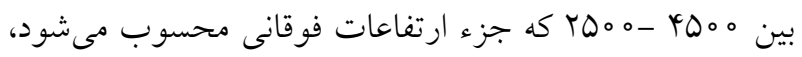
شده است بيشترين بارش برف در غرب منطقه (كوه سبلان) و

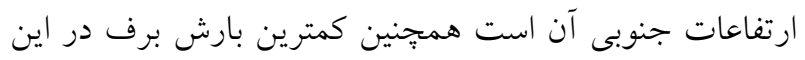

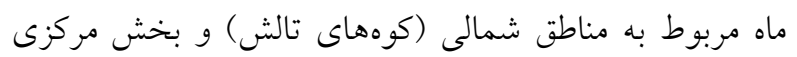
(دهستان ارشق شرقى، دهستان بالغلو، دهستان سردابه، دهستان

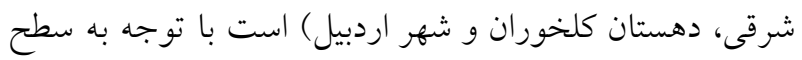
يوشش برف بهدست آمده از آذرماه مساحت برفى اين ماه

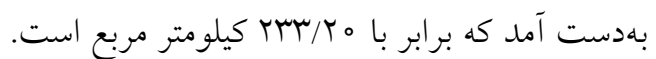

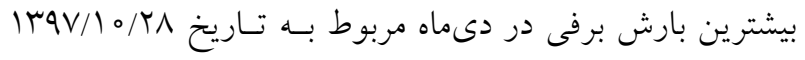

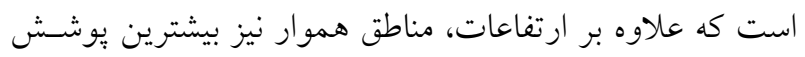
برفى را بهخود اختصاص دادهاند كه با توجه به مقـادير حسداقل دما بين ا- تا بـ است كه دماى هو اى سردترى دارد و با توجه به روزهاى يخبندان تعداد روزهاى يخبنــدان در ايسن مـاه بـين

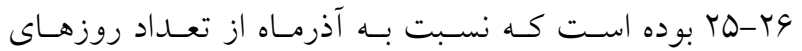

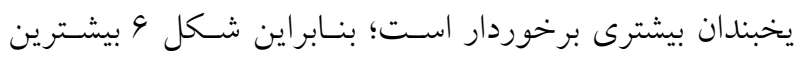

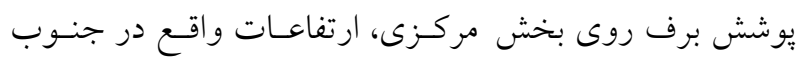

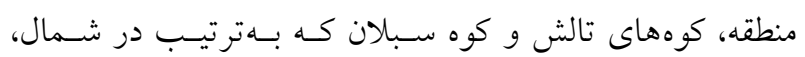

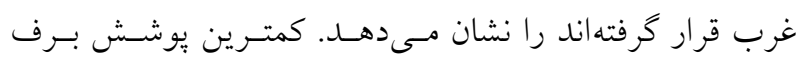

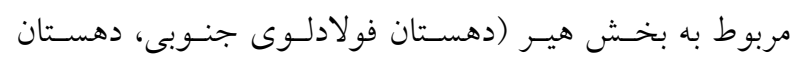

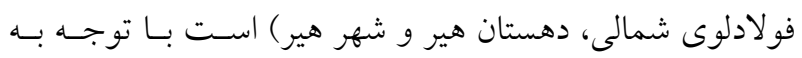

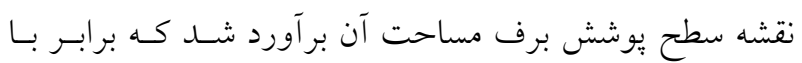




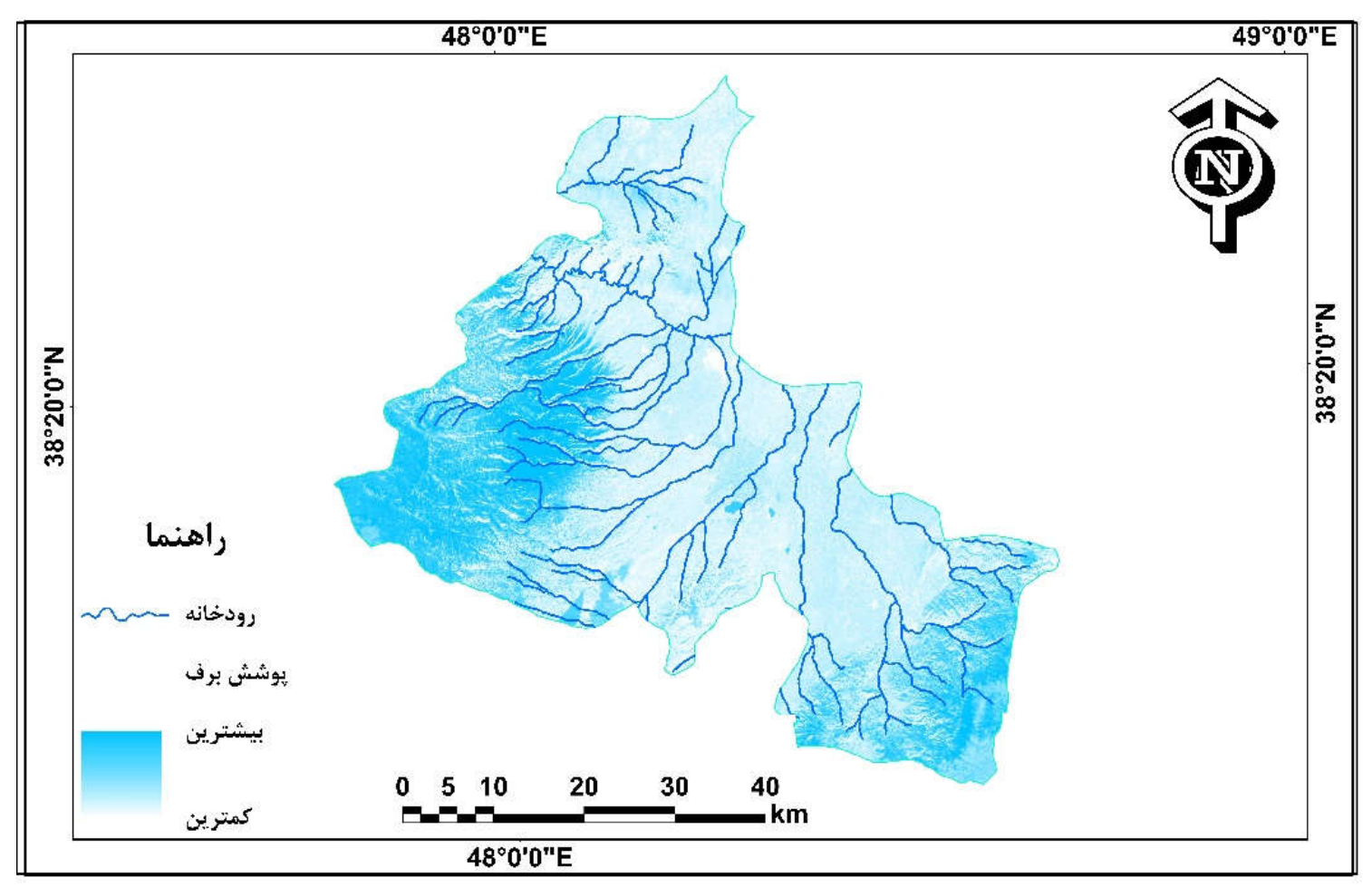

شكل ٪. نقشه سطح يوشش برف آذرماه

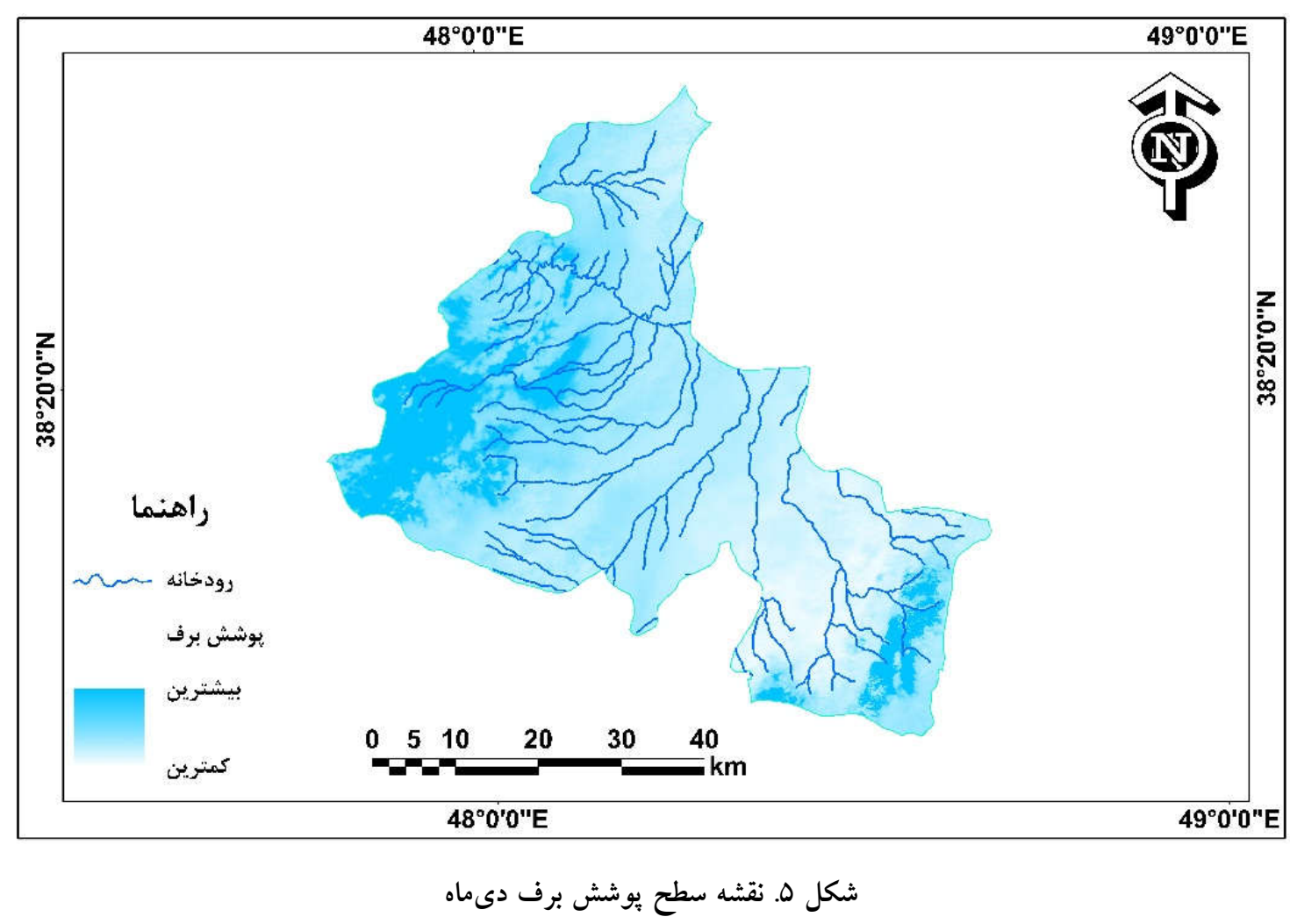


نشريه علوم آب و خاك / سال بيست و ينجم / شماره سوم / باييز 1400

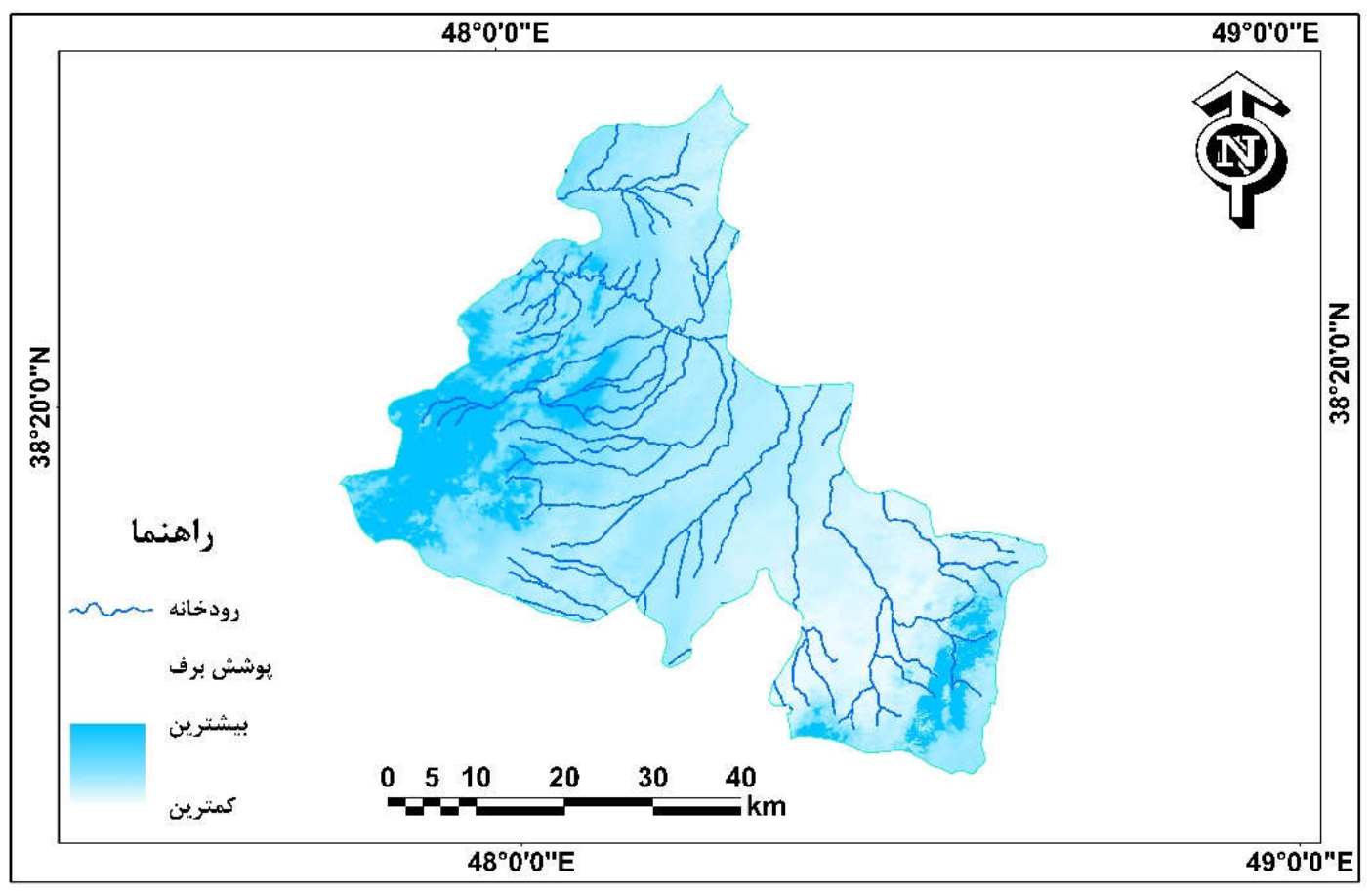

شكل 9. نقشه سطح يوشش برف بهمن ماه

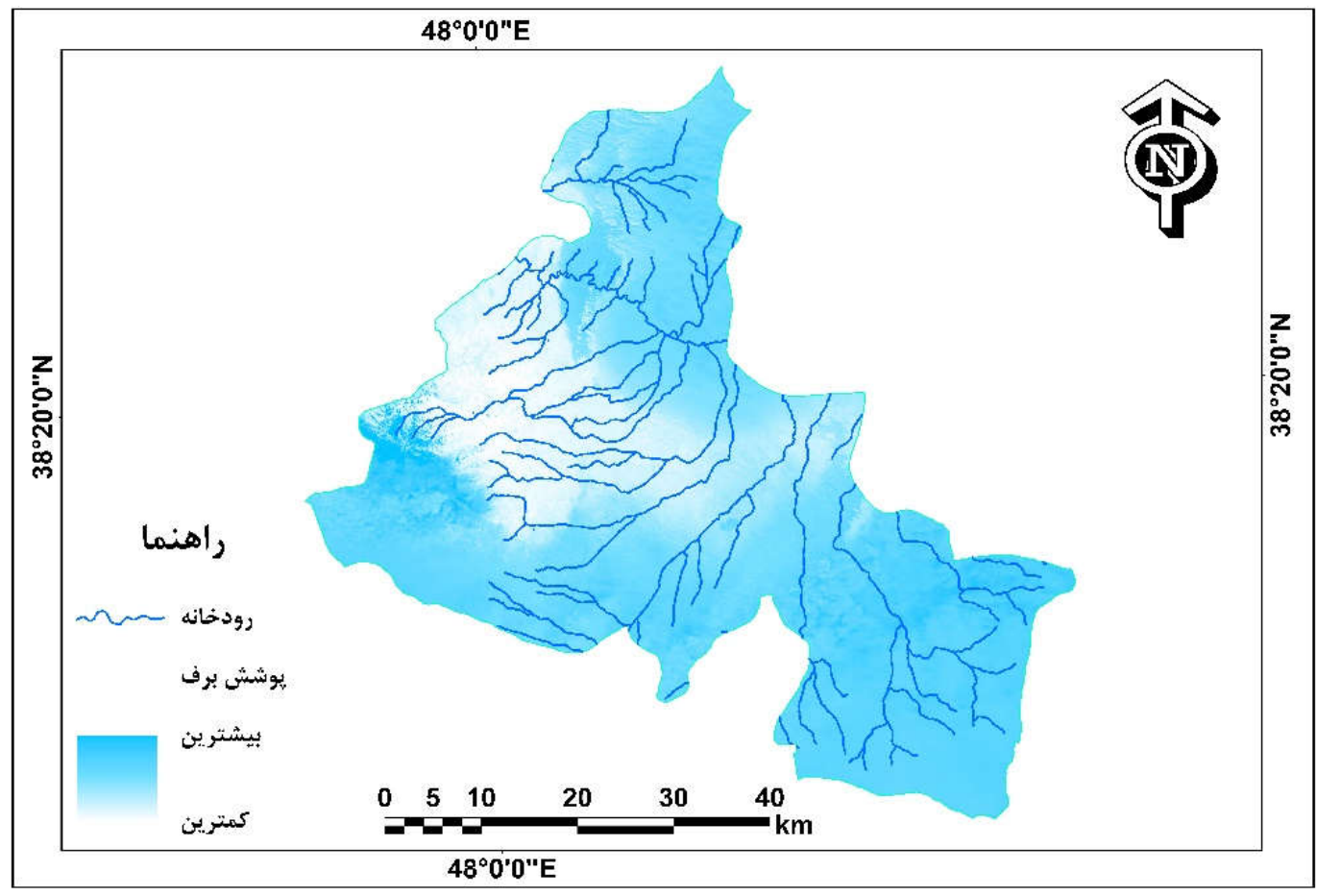

شكل V. نقشه سطح بوشش برف اسفندماه 


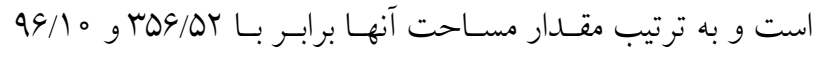

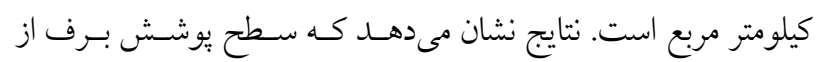

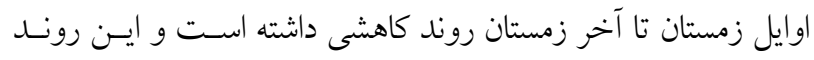

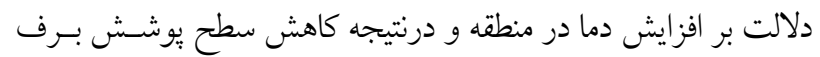

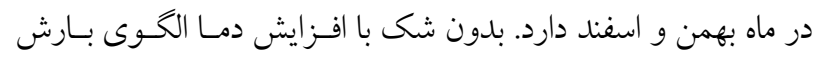
منطقه دستخوش تغيير شده و رزيم بارش زمستانه از بـرف بـهـ بـاران تبديل شده و كاهش ذخيره برفى در حوضـه آبريـز منطقـه را ايجـاد

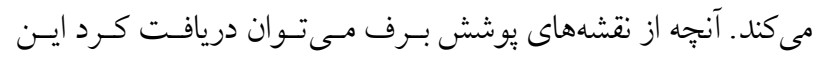

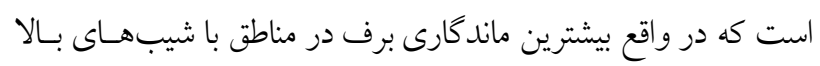

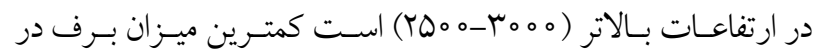
دامنهاى شرقى و بيشترين مقدار آن در دامنـهــاى غربسى بــوده كـهـ

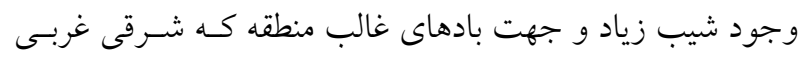

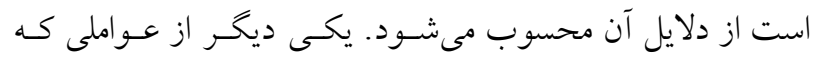

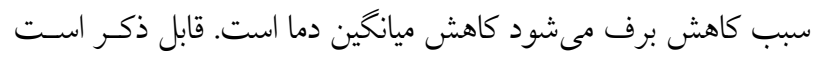

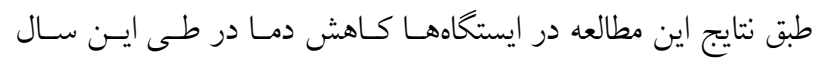

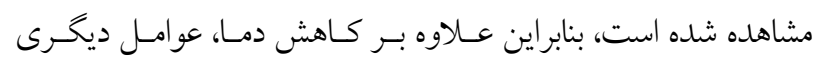

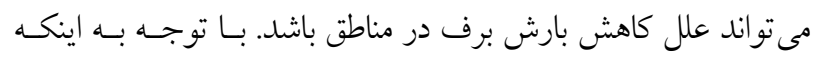

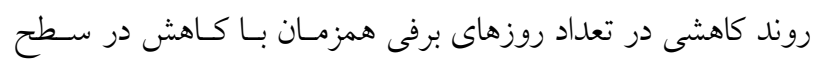

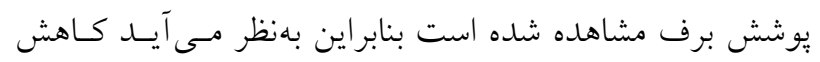

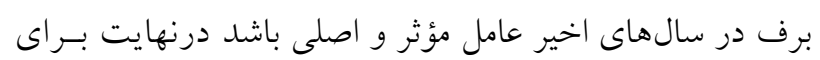

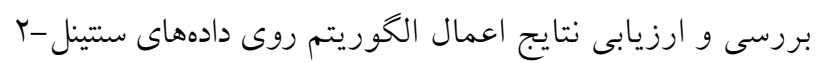

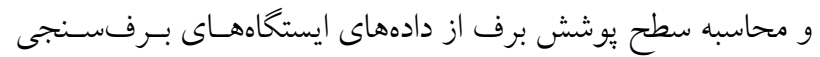

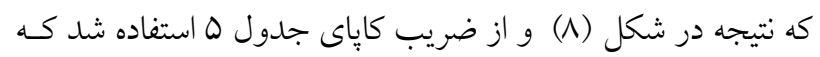

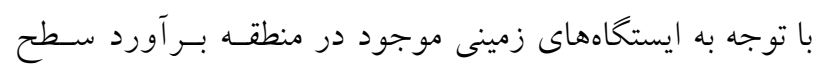

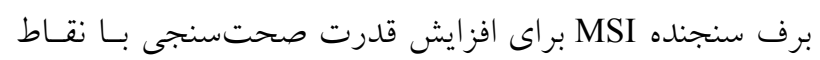

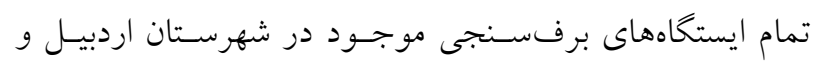

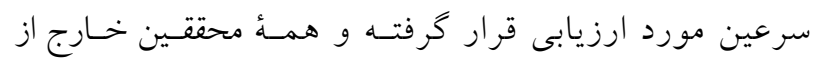

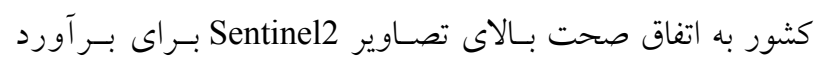

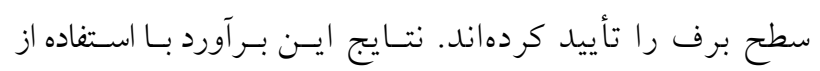
ضـريب كايسا بـراى صـحت تصـاوير Sentinel2 در ايسن منطقـه در تاريخهاى مختلف در جدول ها آورده شده است.

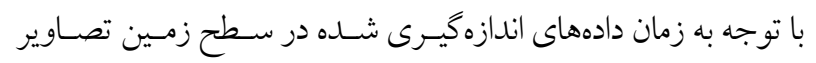

يوشش برف ماه اسـفند در بيشـترين بـارش بـرف در روز 1 TqV/I T/lV

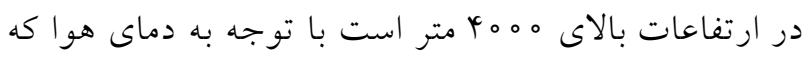

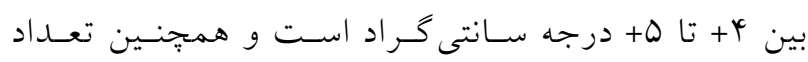

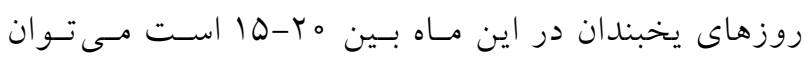

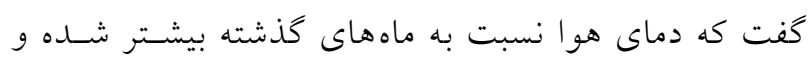

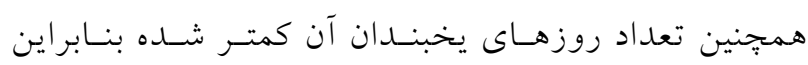

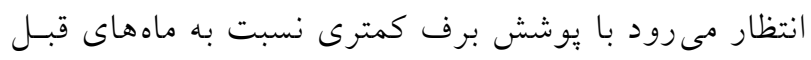

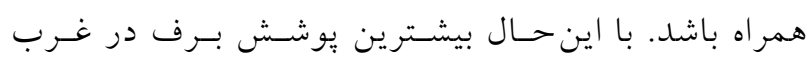

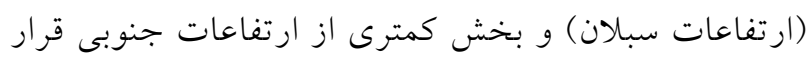

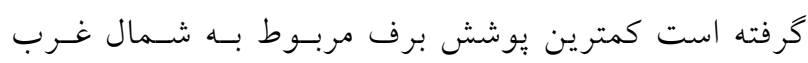

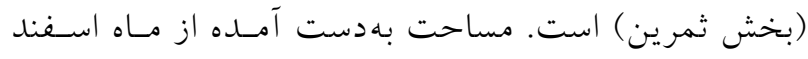

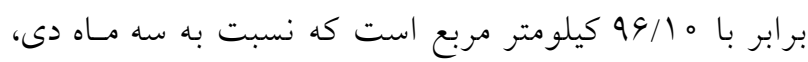

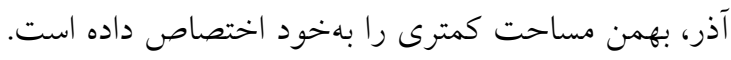

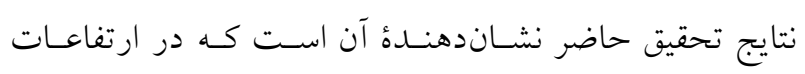

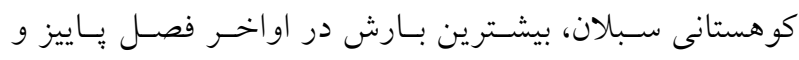

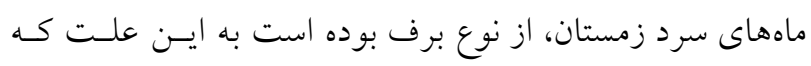

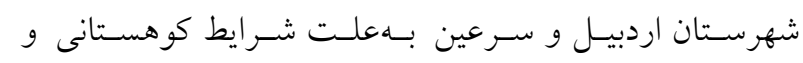

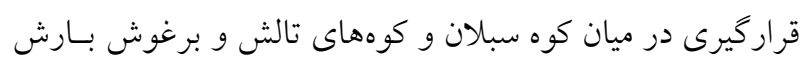

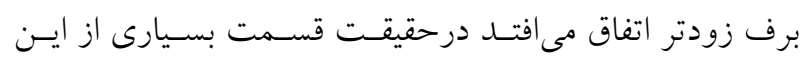

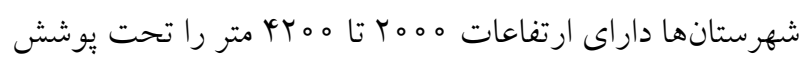
خود قرار مى دهد. با توجه به سطح برف بهدست آمده از طريق

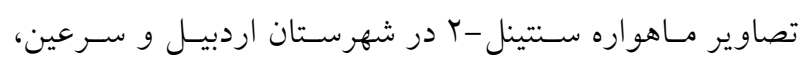
خروجى هر جهار ماه مورد بررسى و ارزيابى قرار كرفت. نتايج

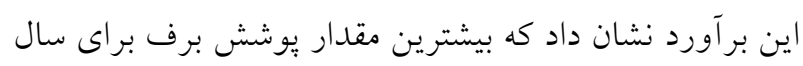

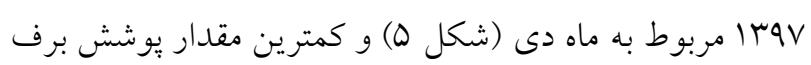

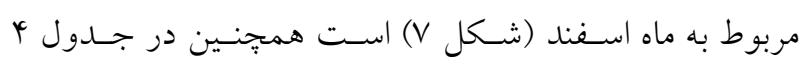

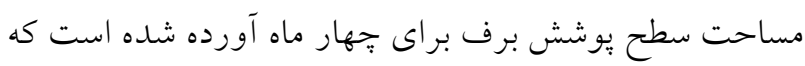

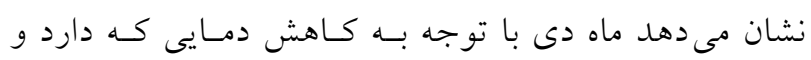

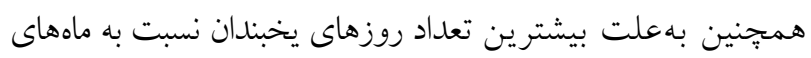

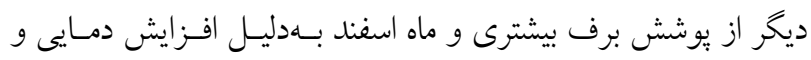

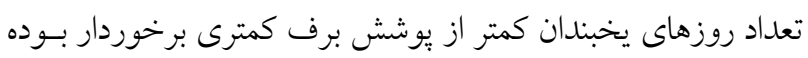


جدول frqV مساحت يوشش برفى منطقه موردمطالعه در سال

\begin{tabular}{|c|c|c|c|c|}
\hline $1 \mathrm{rqV} / \mathrm{V} / \mathrm{TV}$ & $1 r q V / 11 / T \Delta$ & $1 r q V / 10 / r \Lambda$ & $1 r q V / q / r q$ & 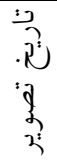 \\
\hline $99 / 10$ & $1 \Lambda \circ / K r$ & TDG/DT & TM/Y & $\begin{array}{l}\overrightarrow{3} \\
\hat{\jmath} \\
\tilde{E} \\
\tilde{E}\end{array}$ \\
\hline
\end{tabular}

جدول ه . بر آورد دقت سطح برف در + توزيع برف در منطقه

\begin{tabular}{|c|c|c|}
\hline تاريخ مشترى تصوير و اندازهيرى زمينى & دقت كلى (درصد) & ضريب كايا (درصد) \\
\hline 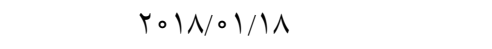 & $91 / \pi$ & $\Lambda F / T$ \\
\hline$Y_{0} \mid V / I Y / Y_{0}$ & $18 / 9$ & No/Dr \\
\hline$r 0 \mid \Lambda / O Y / / Y$ & $91 / \mu$ & $\Lambda r / \Lambda r$ \\
\hline$r \circ \mid \Lambda / O r / \Lambda$ & $90 / 9$ & $\Lambda Q / \circ Y$ \\
\hline ميانخين & $91 / \mu$ & $\Lambda r / 4 Q$ \\
\hline
\end{tabular}

كاربردى در مناطق كو جـى و متوسط يا بزرگ مورد اسـتفاده قـرار

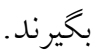
براى يافتن جواب هاى واقعى و برآورد يارامترهاى مربوط به برف از رگرسيون خطى با هدف دقيق بودن رابطه بين نمونههاى مشاهداتى و برآوردى با بهترين برازش خطى در محيط نرمافزار متلب استفاده شد. حاصل مدل رگرسيون خطى بهصورت نمودارى بوده است. شكل ^) كه اين نمودار ير اكنش نقاط مشاهداتى و ضرايب همبستخى در نقاط موجود در سطح منطقه را نشان مىدهد. همجنين براى انجام ارزيابى مدل رگرسيون خطى و اطمينان از دقت بالاى نقشههاى بهدست آمله از جندين شاخص آمارى جون: ريشه ميانخين مجذور خطا (RMSE)، ميانخين مجذور خطا (MSE)، باياس و ضريب همبستخى خطى (BIAS) اعمال اين شاخص ها در نرمافزار EXCEL انجام كرفت كه نتيجه در شكل هاى 9 و ه ا آورده شده است.
مربوط به آن تاريخها انتخـاب و ارزيـابى صـورت گرفـت. در جهـار تاريخ مختلف براى سال و I I مربوط به منطقه مورد مطالعـه بررسى نتايج صورت گرفت. تصاوير بهدست آمده از سطح بوشـش بـرف بـا

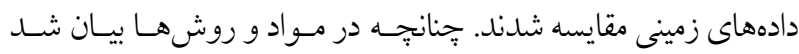
براى انجام ارزيابى و بررسى از معادله رگرسيون خطى استفاده شد كـه.

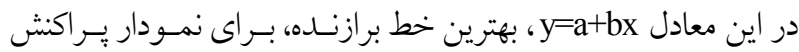

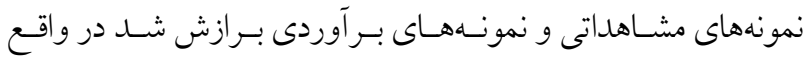
ضرايب a b طورى تعيين شدند كه مجموع تـوان دوم خطاهـا در آن كاهش يافته و بهترين خط برازش شده اسـت انجـام مـوارد فـوق در نرمافزار (MATLAB) انجام گرفت نمودار حاصـل از بــراكنش نقـاط مشاهداتى و خط ركرسيون و ضرايب همبستخى را در نقـاط موجـود در سطح شهرستان اردبيل و سرعين نمايش مى دهل. بر يايه نتـايج

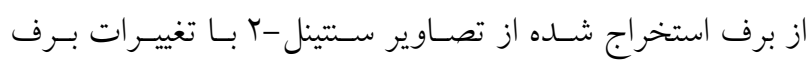

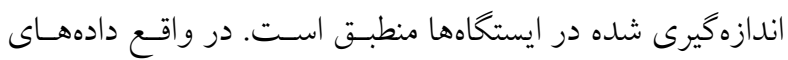

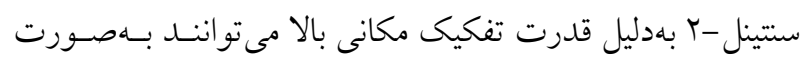




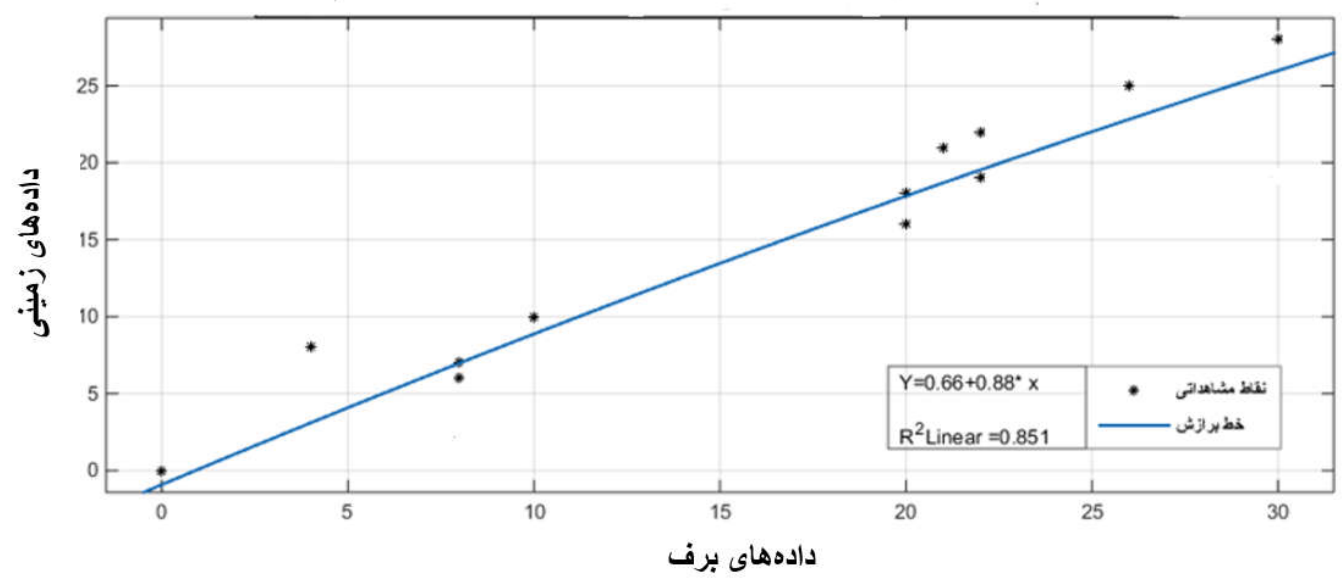

شكل ^. نمودار صحتسنجى دادههاى برف با دادههاى زمينى

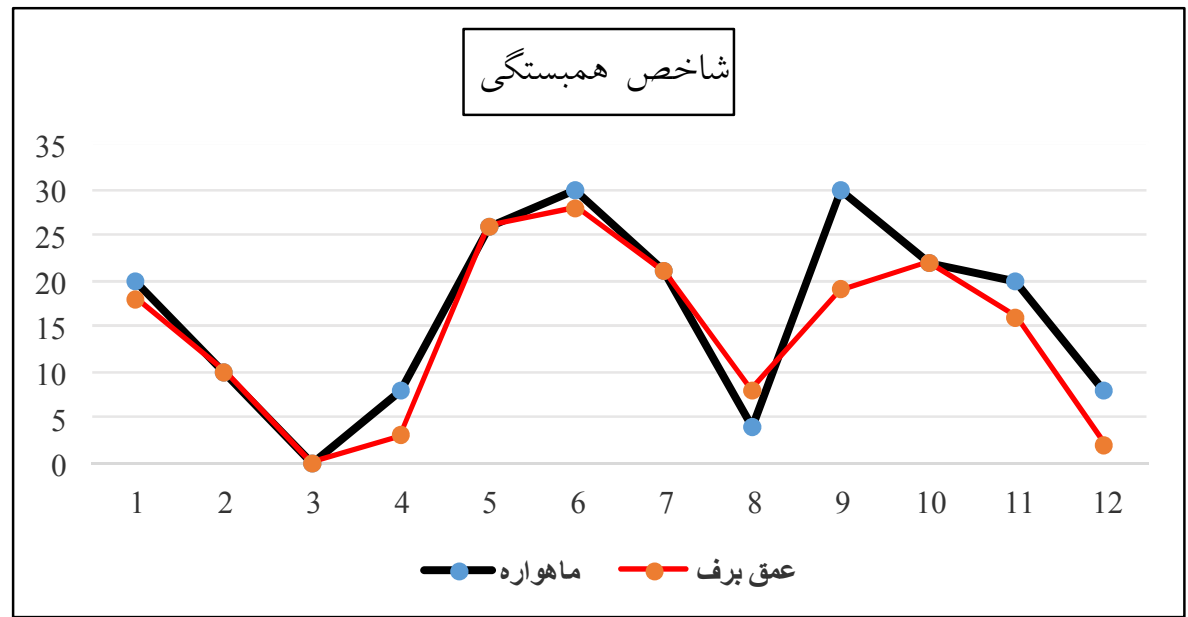

شكل 9. همبستخى بين دادههاى زمينى با برف توليد شده از تصاوير Sentinel

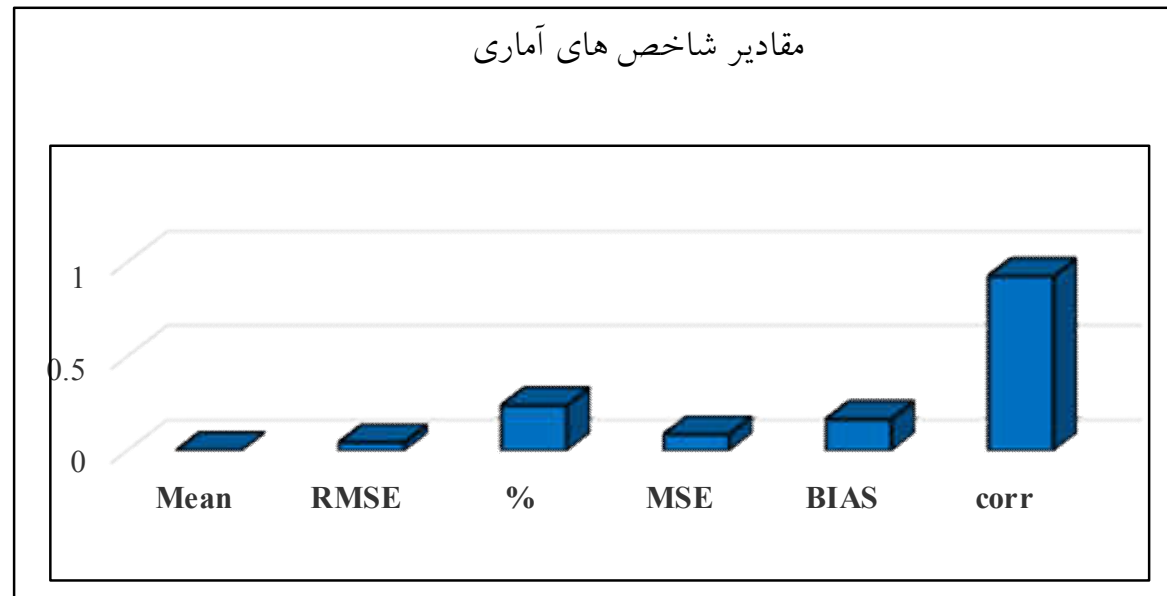

شكل • ا. مقادير شاخصهاى آمارى براى ارزيابى نتايج 
تصاوير سنتينل -r امكان بـايش بوشـش بـرف و بــرآورد ميـزان

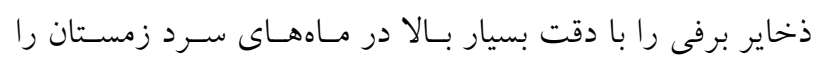

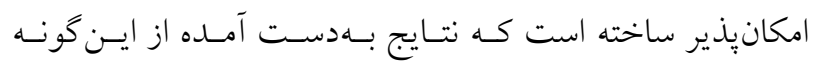

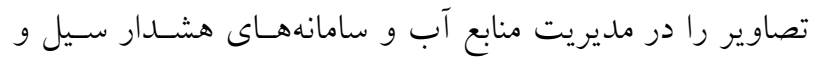

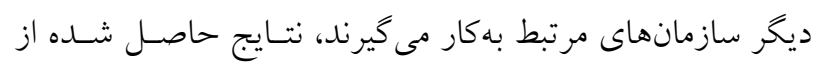

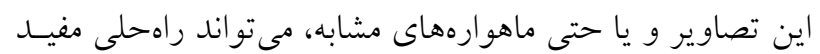

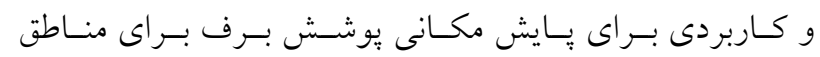

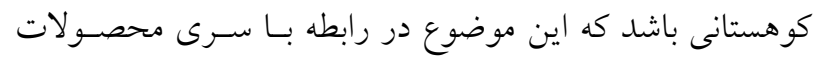

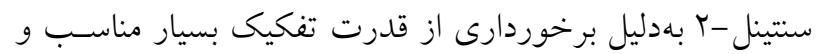

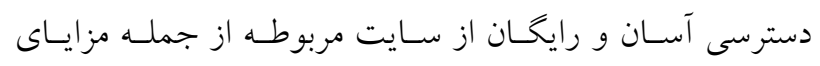

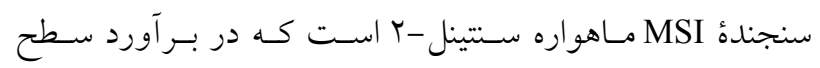

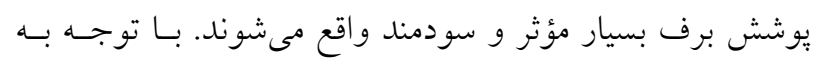

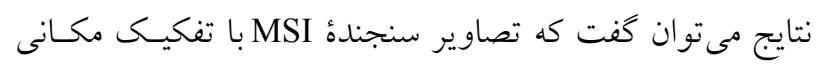

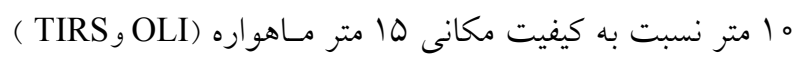

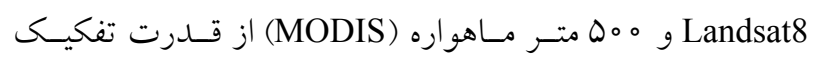

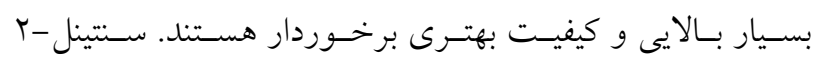

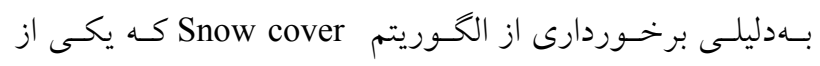

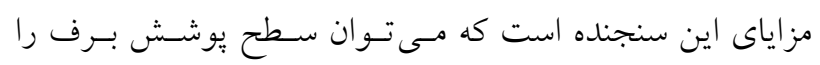

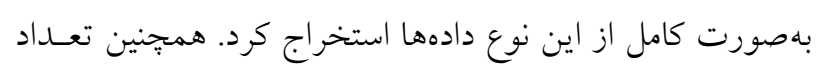

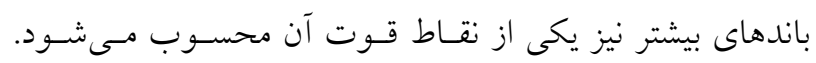

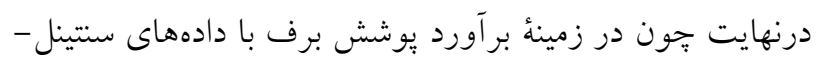

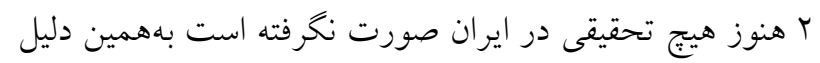

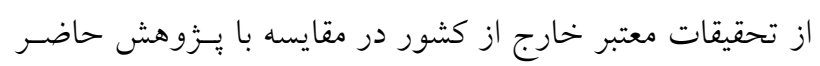

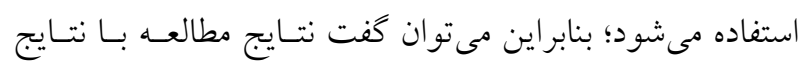

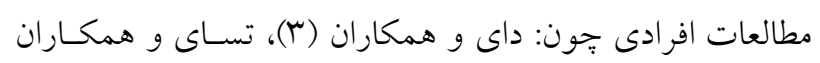

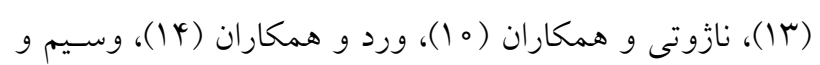

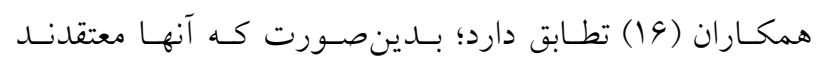

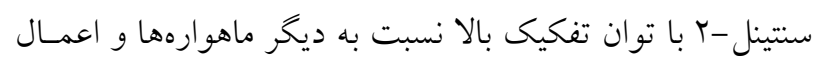

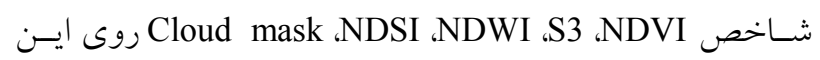

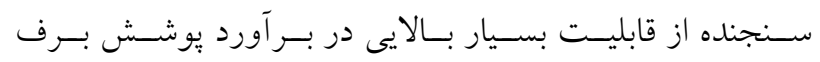

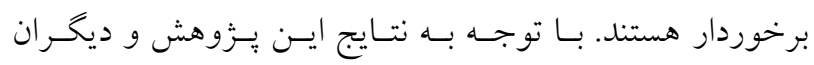

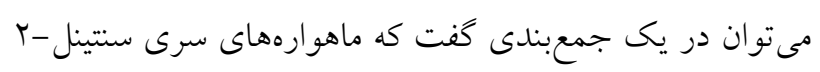

نتايج حاصل از شاخصهاى آمارى BMSE، MIAS، MSE، CORR بهصورت نمودار نشان داد كه مقادير بهدست آمده آنساي

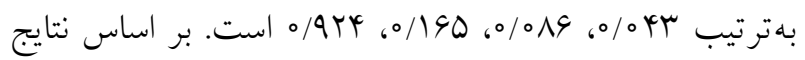

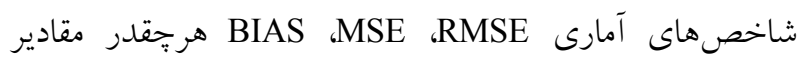
بهدست آمده از آنها به صفر نزديكتر باشد از صحت بالاترى و

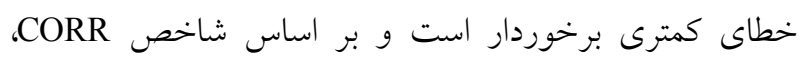

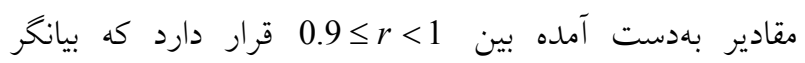

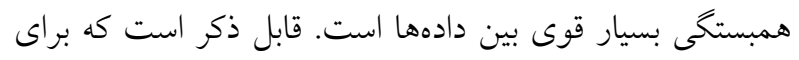

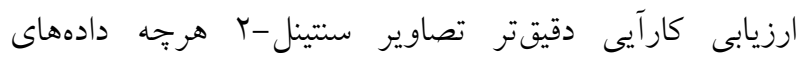

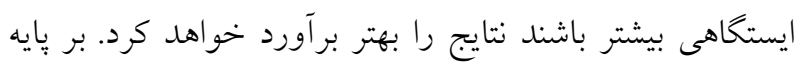

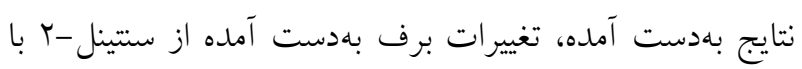

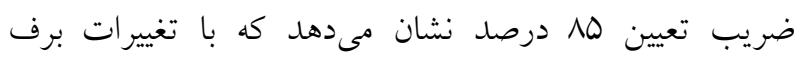
اندازهيرى شده در ايستخاه منطبق است.

\section{بحث و نتيجه گيرى}

در بزوهش حاضر بهمنظور بايش سطح يوشش برف از تصـاوير

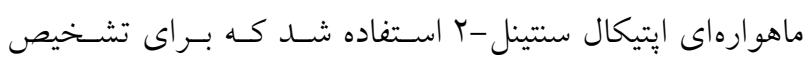

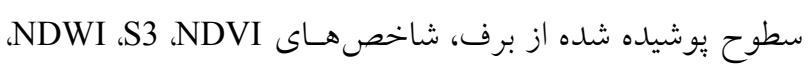
Cloud mask ،NDSI مىدهد طى سال آبى

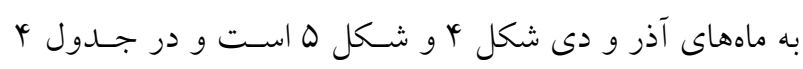

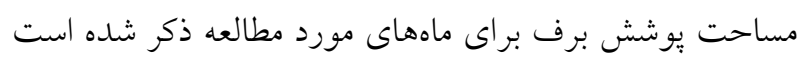

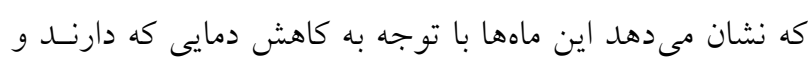

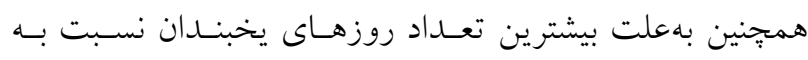

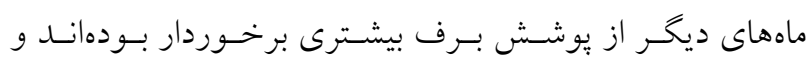

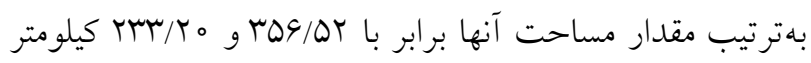

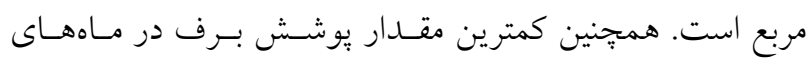
بهمن (شكل 9) و اسفند (شكل V) بهوقوع بيوسته است كه ايسن

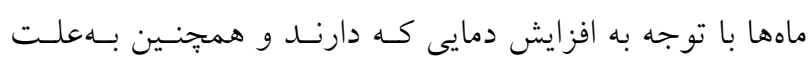

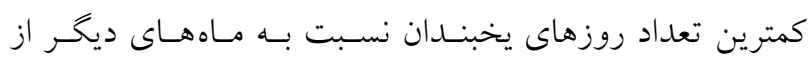

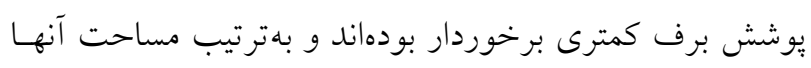

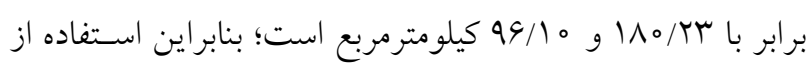




$$
\begin{aligned}
& \text { علاوه بر اسـتخراج يوشـش بـرف اطلاعـات بسـيار بـا ارزشسى در سـطح سـياره زمسين در حسال رخ دادن اسـت را در فواصـل } \\
& \text { ديخرى در ارتباط با برنامههاى زيستمحيطى در مقياس جهانى زمانى كوتاه شناسايى كرد اين مطالعه با نتايج خروجسى خـود و } \\
& \text { مىتوانند فراهم كنند كه از آنها در زمينهُ فعاليتهاى كشـاورزى، با توجه به دادههاى كم ايستخاههاو از طرف ديخر صـعبالعبـور }
\end{aligned}
$$

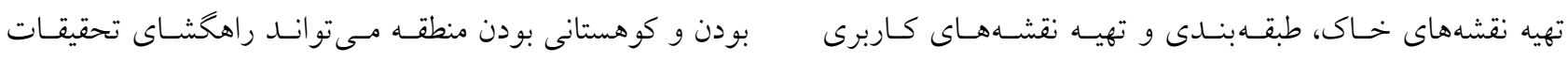

$$
\begin{aligned}
& \text { اراضى، مديريت و كنترل بحران و غيره مسىتـوان اسـتفاده كـرد متعدد برف توسط كارشناسان در منطقه باشد. } \\
& \text { زيرا توان تفكيك زمانى اين ماهواره (ه ا روز) شرايط و امكـانى } \\
& \text { را فراهم آورده است تا بتوان از اين طريق فرايندهاى طبيعى كـهـ }
\end{aligned}
$$

\section{منابع مورد استفاده}

1- Benateau, S., A. Gaudard, Ch. Stamm and F. Altermatt. 2018. Climate change and freshwater ecosystems: Impacts on water quality and ecological status. Hydro-CH2018. Project. Federal Office for the Environment (FOEN), Bern, Switzerland.

2- Borowik, T., N. Pettorelli, L. Sönnichsen and B. Jędrzejewska. 2013. Normalized difference vegetation index (NDVI) as a predictor of forage availability for ungulates in forest and field habitats. European Journal of Wildlife Research 675-682.

3- Du, Y. 2016. Water bodies mapping from Sentinel-2 imagery with modified normalized difference water index at 10-m spatial resolution produced by sharpening the SWIR band. Journal of Remote Sensing 8: 354.

4- Gandhi, M., D. Parthiban and N. Thummalu. 2015. Ndvi: vegetation change detection using remote sensing and gis - A case study of Vellore District. A Procedia Computer Science 1199-1210.

5- Hagolle, O. M. and C. Huc. 2018. MAJA ATBD algorithm theoretical basis document. Approved by M. Dejus, CNES, Project Manager, Remote Sens, 37 p.

6- Hanafi Nairi, N. 1393. Investigating the application of CIT climate-tourism index in determining mountain climate tourism case study: Ardabil county, Master's Thesis in Geography and Tourism Planning, Regional Tourism Planning, Tabriz University.

7- Liu, Y., L. Li, J. Yang, X. Chen and J. Hao. 2017. Estimating snow depth using multi-source data fusion based on the D-InSAR method and 3DVAR fusion algorithm. Journal of Remote Sensing 1-17.

8- Masson, T. H., M. Dumont, M. Mura, P. Sirguey, P. Gascoin, J. Dedieu and C. Chanussot. 2018. An assessment of existing methodologies to retrieve. Snow cover fraction from MODIS data. Journal of Remote Sensing 10: 619.

9- Mott, R., V. Vionnet and T. Grünewald. 2018. The seasonal snow cover dynamics: review on wind-driven coupling processes. Frontiers in Earth Science https://doi.org/10.3389/feart.2018.00197.

10-Nagajothi, V., C. Priya and P. Sharma. 2019. Snow cover estimation of western himalayas using sentinel-2 high spatial resolution data. Indian Journal of Ecology 88-93.

11-Nagler, T., H. Rott, E. Ripper, G. Bippus and M. Hetzenecker. 2016. Advancements for snowmelt monitoring by means of Sentinel-1 SAR. Journal of Remote Sensing 10: 619.

12-Souza, M. V., C. Barbosa, L. Carvalho, D. Jorge, F. Lobo and N. Novo. 2017. Assessment of atmospheric correction methods for Sentinel-2 MSI images applied to amazon floodplain lakes. Journal of Remote Sensing 9: 322.

13-Tsai, Y., A. Dietz, C. Künzer and N. Oppelt. 2019. Snow cover extent mapping based on dual-polarimetric Sentinel1 SAR data. Geophysical Research Abstracts. Remote Sensing 11: 1456.

14-Varade, D., and O. Dikshit. 2018. Estimation of surface snow wetness using sentinel-2 multispectral data. Journal of Remote Sensing and Spatial Information Sciences 223-228.

15-Wang, Sh., B. Yang, Y. Zhou, F. Wang, R. Zhang and Q. Zhao. 2018. Snow cover mapping and ice avalanche monitoring from the satellite data of the sentinels. Journal of Remote Sensing and Spatial Information Sciences 1765-1772.

16-Wasim, B. M., S. Gascoin and L. Hanich. 2018. Assimilation of Sentinel-2 data into a snowpack model in the high atlas of Morocco. Peer-reviewed version available at Remote Sensing 1-22. 


\title{
Estimation of Snow Cover Level in Ardebil and Sarein Cities Using Sensor Data Sentinel2 MSI Satellite
}

\author{
S. Asghari Saraskanroud ${ }^{1 *}$ and R. Modirzadeh ${ }^{2}$
}

(Received: June 7-2020; Accepted: December 19-2020)

\begin{abstract}
Snow cover is one of the important climatic elements based on which climate change may have a special effect. In general, climate change may be reflected in different climatic elements. Therefore, it is very important to study and measure changes in snow level as one of the important sources of water supply. Ardebil and Sarein cities are located at $48^{\circ} 18^{\prime}$ east longitude and $38^{\circ} 15^{\prime}$ north latitude. In this study, Sentinel-2 optical satellite was used to monitor the snow cover surface in 2018, and NDVI, S3, NWDI, NDSI, Cloud mask indices were applied to detect snow-covered surfaces using ArcGIS and Snap software. Next, to validate the snow maps extracted from the images, it was compared with the snow data in terrestrial stations using linear regression in MATLAB software and to evaluate the accuracy of the model statistical indices including RMSE, MSE, BIAS, CORR were used. The present study showed that according to Ardabil city climatic conditions, maximum-snow covered area in January with an area of $356.52 \mathrm{~km} 2$ and minimum snowcovered area in March with an area of $96.10 \mathrm{~km} 2$. The highest snow cover is observed in the high slope areas in the western slopes (Sabalan Mountain Heights) and the lowest snow cover is observed in the lower eastern slopes. The results of linear regression with generalization coefficient are $85 \%$ and the results of statistical indices of error are equal to MSE: 0.086, BASAS: 0.165, CORR: 0.924, and RMSE: 0.03. Correlation relationships between terrestrial data and estimated snow maps showed a high degree of correlation. This result is statistically significant at the $99 \%$ level. The use of optical images in estimating snow levels is very cost-effective due to the size of the areas and the high cost of installing snowmobiles. The results obtained in the present study indicated that traditional radar images with high spatial resolution and good correlation with terrestrial data can be a good alternative to snowmobiling ground stations at high altitudes or in passable areas.
\end{abstract}

Keywords: Snow coverage level, Sentinel-2, NDSI index, S3 index, Sarein, Ardebil

1. Department of Natural Geography, Faculty of Literature and Humanities, Mohaghegh Ardabili University, Ardabil, Iran.

2. Department of Remote Sensing and Geographic Information System, Mohaghegh Ardabili University, Ardabil, Iran.

*: Corresponding author, Email: s.asghari@uma.ac.ir 